by Hafiz Ur Rehman ${ }^{\text {** }}$,Hiroshi Yamamoto ${ }^{\text {, Tayyaba Mateen }}{ }^{1}$, Kazuaki Okamoto ${ }^{2}$, Tzen-Fu Yui , Masaru Terabayashi, and Kazuaki Nanamura ${ }^{5}$

\title{
Oxygen isotope data of quartz from San-yo and Ryoke belt granites, schists, and siliceous veins: constraining the effects of ${ }^{18} \mathrm{O}$-rich fluids on granitic magma
}

\author{
${ }^{1}$ Graduate School of Science and Engineering, Kagoshima University, Kagoshima, Japan; *Corresponding author, E-mail: hafiz@sci.kagoshima-u.ac.jp \\ ${ }^{2}$ Department of Earth Sciences, Faculty of Education, Saitama University, Saitama, Japan \\ ${ }^{3}$ Institute of Earth Sciences, Academia Sinica, Taipei, Taiwan \\ ${ }^{4}$ Faculty of Engineering and Design, Kagawa University, Takamatsu, Japan \\ ${ }^{5}$ Division of Instrumental Analysis Research Support Center, Kagoshima University, Japan
}

(Received: February 8, 2021; Revised accepted: June 8, 2021)

https://doi.org/10.18814/epiiugs/2021/021012

Oxygen isotope data $\left(\delta^{18} O\right)$ of quartz are reported for the San-yo and Ryoke belt granites, metamorphic rocks, and late-stage siliceous veins. The analyzed quartz showed $\delta^{18} O$ values of $9.7-12.9 \%$ (relative to VSMOW) in granites, $15.1-17.3 \%$ in biotite schist, 16.4-17.8\% in siliceous schist. The $\delta^{18} O$ values of quartz in foliation-parallel and -normal veins are $16.6 \%$ and $17.3 \%$, respectively. The $\delta^{18} \mathrm{O}$ values of quartz in the granite samples are relatively higher than those crystallized from I-type granite magma (ca. 5-8\%) and similar with values of S-type granite magma (ca. 9-12\%). These features suggest partial melting of the chemically modified crust with sedimentary precursors to form the parental magma of granites. Hafnium isotope data of zircons from those granites, reported in an earlier publication, exhibited by $\varepsilon_{H f}(t)$ values between +1.1 and -4.8 , provide additional evidence for the formation of the granites from a continental crust with some incorporation of hydrothermally altered reworked crust before partial melting. The relatively higher $\delta^{18} \mathrm{O}$ values (> 15\%) of quartz in siliceous veins indicate their precipitation from silica-and ${ }^{18} \mathrm{O}$-rich fluids that were extracted from the slab-dehydration process during late-stages of their evolution.

\section{Introduction}

Oxygen isotope compositions referred as $\delta^{18} \mathrm{O}\left(\right.$ the ${ }^{18} \mathrm{O} /{ }^{16} \mathrm{O}$ ratio) in per mil \%o, in the sample relative to Vienna Standard Mean Ocean Water (VSMOW) provide important constraints on understanding the origin of melt (magma source) and fluids derived from the dehydration of subducted crust (metamorphism) and late-stage events (hydrothermal alteration). Typical mantle-derived rocks (unaltered basalts/ gabbro) show a narrow range of $\delta^{18} \mathrm{O}$ values ca. $+5.7 \pm 0.3 \%$ but exhibit a wider range if basalts/gabbros are altered ca. 0 to $+12 \%$ (Kolodny and Epstein, 1976; Muehlenbachs, 1998; Valley et al., 2005; Hoefs, 2009 and references therein). The wide range of $\delta^{18} \mathrm{O}$ values in rock represents the interaction of surface waters in the Earth's rock cycle. In addition, melting of ${ }^{18} \mathrm{O}$-rich crustal rocks can result in magmas with elevated $\delta^{18} \mathrm{O}$ values. Hydrothermal alteration is another important mechanism that modifies $\delta^{18} \mathrm{O}$ values in rocks and their constituent minerals (e.g., Eiler et al., 1998). Generally, igneous rocks of crustal origin (granitoids) exhibit $\delta^{18} \mathrm{O}$ values in a range from ca. +5 to $+8 \%$ in the so-called "I-type granites", from +9 to $+12 \%$ in the so-called "S-type granites", and the values further increase in rocks derived from sedimentary sources or their metamorphosed equivalents ca. +12 to $+20 \%$ (Kolodny and Epstein, 1976; Muehlenbachs, 1998; Valley et al., 2005; Hoefs, 2009). Therefore, study of the oxygen isotope compositions in rocks and their constituent minerals helps in understanding the magmatic source and their isotopic variations evidence the effects of late-stage geological processes.

Southwest Japan is divided into the Inner Zone (Japan Sea side) and the Outer Zone (Pacific Ocean side) separated by a regional tectonic contact known as the Median Tectonic Line or "MTL" (Miyashiro, 1961). The Inner Zone is characterized by Paleozoic to Mesozoic sedimentary and low-pressure/high-temperature (LP/HT) metamorphic sequence and intrusive rocks. The Outer Zone is represented by the high-pressure/low-temperature (HP/LT) Sanbagawa metamorphic belt, and relatively younger Shimanto belt accretionary complex (Iida et al., 2015 and references therein). The Ryoke and Sanbagawa metamorphic belts form the classic 'paired' metamorphic belts of southwest Japan reported by a number of authors (e.g., Miyashiro, 1961, 1973; Banno and Nakajima, 1992; Brown, 1998, 2010; Wallis and Okudaira, 2016). The metasedimentary successions and associated granitoids provide natural sites to understand the subduction and collision-related processes, thermal regimes, and tectonic settings where the subducted plate (along the Pacific Ocean side) preserves the HP/LT lithologies and the overriding plate (along the Japan Sea side) retains the LP/HT metamorphic rocks and emplacement of the contemporaneous granitoids. 
The Ryoke metamorphic belt (Fig. 1a) is mainly composed of pelitic-psammitic schists and gneisses that display a well-developed foliation along the strike (east-west trend) of the belt, and intruded by numerous granitoid bodies that are further subdivided into the San-yo belt granites to the north and the Ryoke belt granites to the south (Kojima, 1953; Okamura, 1957, 1960; Koide, 1958; Miyashiro, 1961; Hayasaka et al., 1983; Higashimoto et al., 1983; Kagami et al., 1992; Nakajima, 1994, 2018; Yamamoto, 1994; Isozaki, 1996; Maruyama et al., 1997; Brown, 1998; Jahn, 2010; Terabayashi et al., 2010 and references cited therein). A number of publications have discussed the tectono-metamorphic relationships of metamorphic rocks and granitoids. A general consensus exists that schists and gneiss of the Ryoke metamorphic belt, particularly in the Southwest Japan, were thermally affected by the intruding granitoids (e.g., Nureki, 1974; Ikeda, 1993, 1998; Okudaira et al., 1993, 2009). Several granitoids are considered to be syn-tectonic (syn-deformational) whereas others are post-tectonic (Higashimoto et al., 1983; Okudaira et al., 1995; Suzuki et al., 1996; Suzuki and Adachi, 1998). Therefore, regional metamorphism and intrusive granite magmatism are closely associated. In addition, ubiquitous quartz veins (foliation-parallel and foliation-normal) are observed that penetrate through the schists.

Miyashiro (1967) discussed that the formation of paired metamorphic belts in the Japanese islands during the Cretaceous time was due to the convection and mantle degassing along the deep-reaching shear zones. This process likely resulted in generating the granitic magma due to partial melting of the overlying continental crust, assimilating the country rocks during the magma ascent. Contamination of magma by the overlying sedimentary successions is likely in such situations. Investigating oxygen isotope $\left({ }^{18} \mathrm{O} /{ }^{16} \mathrm{O}\right)$ values of quartz, (a dominant constituent mineral of granites, surrounding metamorphic rocks, and in the penetrating quartz veins that preserve geochemical records) is therefore useful to understand the origin of granitic magma, the effects from the surrounding metasedimentary sources on the magma, and role of fluids that precipitated the late-stage quartz veins within the metamorphic rocks. Although previous studies (Matsuhisa et al., 1972; Honma and Sakai, 1975; Ishihara, 1977; Kagami et al., 1992; Ishihara and Matsuhisa, 2002) reported oxygen isotope data for granites from the San-yo and Ryoke belts and the surrounding metamorphic rocks,
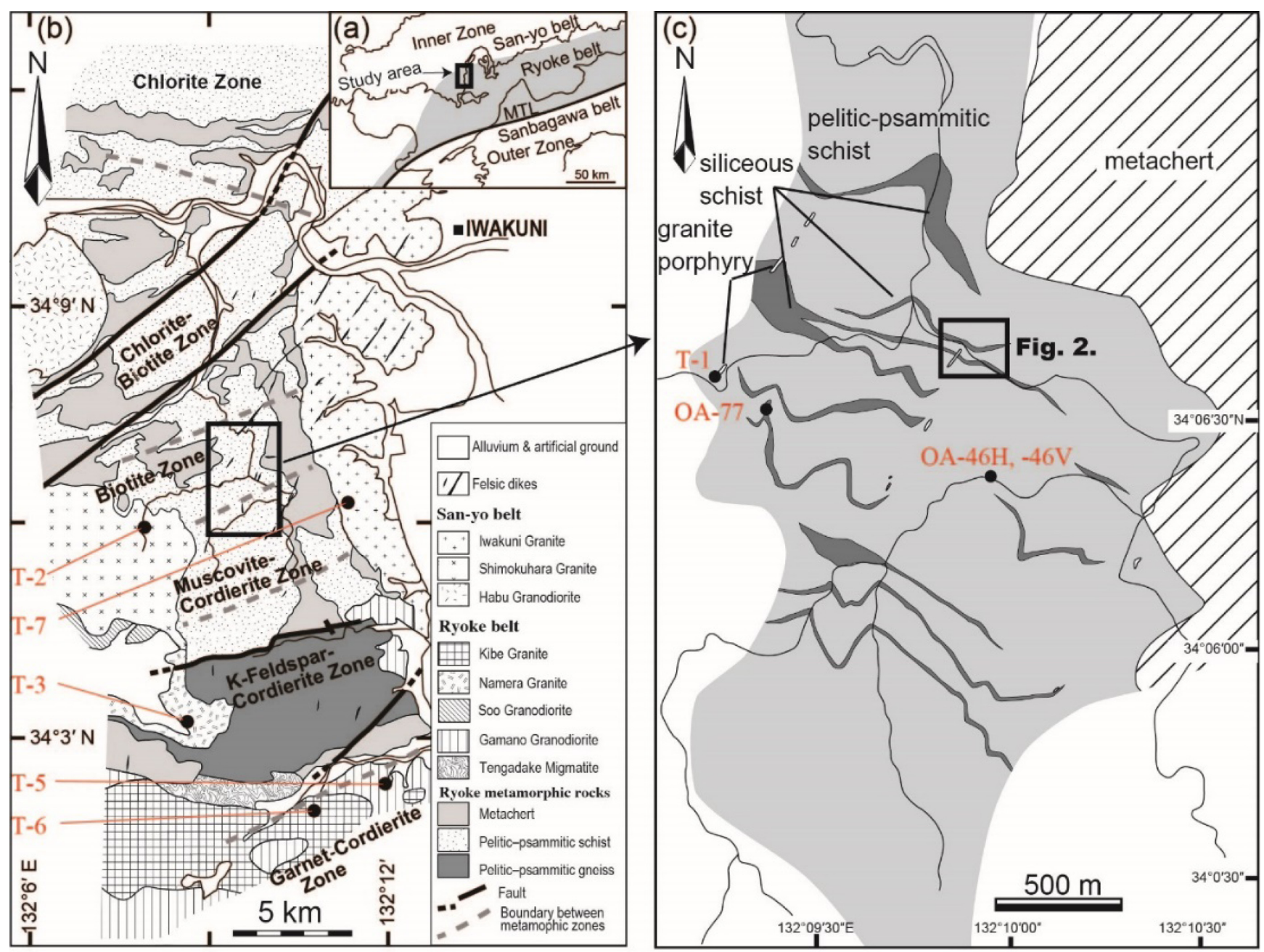

Figure 1. (a) A simplified sketch showing the location of San-yo, Ryoke, and Sanbagawa belts in the Inner and Outer Zones of southwest Japan. Box in the middle represents the area of this study. (b) Simplified geological map showing the granites of the San-yo and Ryoke belts and schists/gneisses of the Ryoke metamorphic belt exposed in the Iwakuni area (modified after Higashimoto et al., 1983). Metamorphic zonation is adopted from Ikeda (1993, 2004). Samples used in this study were collected from locations marked as filled circles with labels (see details in Table 1 for sample descriptions). (c) Enlarged view of the box shown in Fig. 1 b with samples collected and are marked as filled circles with labels. 
no data exist that show combined results of oxygen and Hf isotope on these rocks. Moreover, little is known regarding the origin of the latestage fluids that precipitated the foliation-parallel and foliation-normal quartz veins within the metamorphic rocks. In order to understand the above factors, oxygen isotope ratios of purified quartz crystals from granites, granite porphyry dike, biotite and siliceous schists, and quartz veins along with whole-rock major and some trace element compositions were examined. The geochemical data combined with zircon Hf isotope ratios provide useful constraints regarding the origin of the granitic magma, the geochemical effects of the surrounding metasedimentary precursors on the emplaced granites, and the source of fluids that precipitated the late-stage silicic veins within the metasedimentary rocks.

\section{Geological Background}

Granitic bodies exposed in the Iwakuni area in southwest Japan are subdivided into two major zonal arrangements known as the San-yo belt (also known as the Hiroshima Granites) in the north and the Ryoke belt in the south (Fig. 1b). Granites in the San-yo belt are further subdivided into Iwakuni Granite, Shimokuhara Granite, and Habu Granodiorite whereas those in the Ryoke belt include Kibe Granite, Namera Granite, Soo Granodiorite, Gamano Granodiorite, and Tengadake Migmatite (Higashimoto et al., 1983). In places, subparallel dikes of granite porphyry known as the "Rokuroshi granite porphyry dike swarm" (Higashimoto et al., 1983) intrude the metamorphic rocks and the Iwakuni Granite (Fig. 1c). Based on structural features and geochemistry, granites from the San-yo belt were interpreted as predominantly of I-type that formed at shallow crustal conditions whereas granites from the Ryoke belt were regarded as deep facies (Ishihara, 1977; Nakajima, 1994; Kagami et al., 1992).

Radiometric dating of the granites of the San-yo and Ryoke belts shows an age span between 112 and $70 \mathrm{Ma}$, based on the Rb-Sr, K-Ar age of biotite and whole-rock data, $\mathrm{U}-\mathrm{Pb}$ age of zircon, and $\mathrm{U}-\mathrm{Th}-\mathrm{Pb}$ CHIME age of monazite (Kawano and Ueda, 1966; Shigeno and Yamaguchi, 1976; Higashimoto et al., 1983; Okano and Honma, 1983; Kagami et al., 1988; Nakajima et al., 1990, 1993; Nakajima, 1994, 2018; Okudaira et al., 1995; Suzuki et al., 1996; Herzig et al., 1998; Suzuki and Adachi, 1998). Based on the U-Pb zircon ages, Skrzypek et al. (2016). refined the span between 105 and 94 Ma for the Ryoke granites. Granites in the San-yo belt also revealed more or less identical ages to those in the Ryoke belt, spanning between 124 to $90 \mathrm{Ma}$ (Higashimoto et al., 1983; Owada et al., 1995; Suzuki et al., 1996; Suzuki and Adachi, 1998). Mateen et al. (2019) carried out U-Pb combined with $\mathrm{Hf}$ isotope analysis on zircons separated from granites from the San-yo and Ryoke belts and reveled an age span of 106 to $92 \mathrm{Ma}$.

Ikeda $(1993,1998)$ identified six metamorphic zones (from north to south) in the Ryoke belt as (1) the chlorite Zone, (2) the chlorite-biotite Zone, (3) the biotite Zone, (4) the muscovite-cordierite Zone, (5) the K-feldspar-cordierite Zone, and (6) the garnet-cordierite Zone (Fig. 1b). Radiometric dating of the metamorphic rocks is not very clear, especially for the lowest grade rocks because of their formation under lower temperature conditions which makes growth of the metamorphic zircons unlikely. Rather, the zircons or monazite that occur in those schists may contain information about their detrital origin. Sev- eral earlier studies conducted on biotite $(\mathrm{Rb}-\mathrm{Sr}$ and $\mathrm{K}-\mathrm{Ar})$ show coeval age range (105 to $65 \mathrm{Ma}$ ) for the Ryoke metamorphism similar to that found in the granite emplacement in the study area, however, the age data reported show older values in the west and younger in the east (Nakajima, 1994; Owada et al., 2014 and references therein). Skrzypek et al. (2018) revisited the age of the Ryoke metamorphic rocks and refined the span between 103 and $86 \mathrm{Ma}$ on the basis of $\mathrm{U}-\mathrm{Pb}$ on zircon and monazite. Terabayashi et al. (2010) reported a number of thin layers of siliceous schists within the biotite and muscovitecordierite zones and numerous quartz veins that penetrate though the pelitic/siliceous schists (Fig. 2a).

\section{Sample Description}

Samples of granites from the San-yo and Ryoke belts (Fig. 1b), biotite and siliceous schists from the Ryoke metamorphic belt (Fig. 1c), and the penetrating quartz veins (Figs. $2 a$ and $2 b$ ) were used for this study. Petrography and structural or textural features of some of the samples were reported in earlier studies (e.g., Terabayashi et al., 2010; Mateen et al., 2015, 2019). For the reader's convenience, we reproduce the geological information that is related to this study.

Petrographic details of the San-yo belt granites (Figs. 3a and 3b),
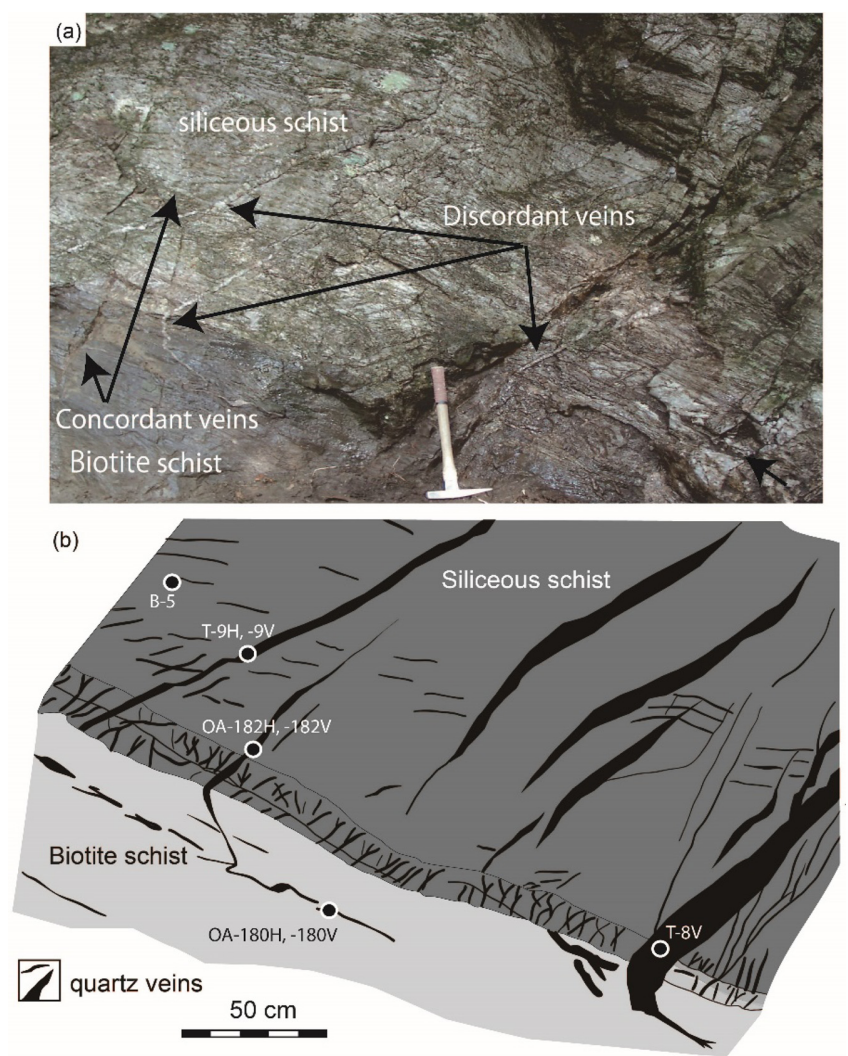

Figure 2. (a) Field photograph of the biotite schist, siliceous schist, and quartz veins that are concordant as well as discordant to the host metasedimentary rocks (image is taken from an outcrop marked as rectangular box in Fig. 1c, and is the same outcrop that was published in Terabayashi et al., 2010). (b) Sketch of the outcrop mentioned above, showing the biotite and siliceous schists, and the extensive networking of quartz veins. Samples collected are marked and details are shown in Table 1. 
(a) Shimokuhara Granite (T-2)

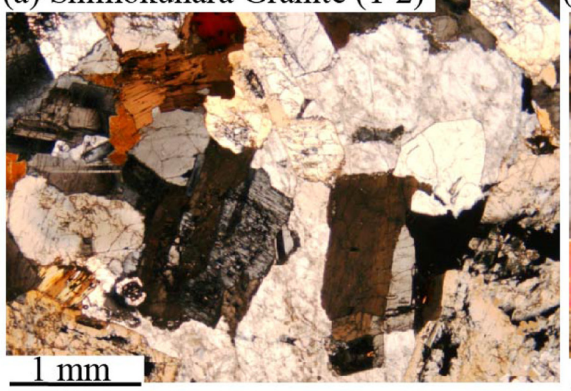

(d) Gamano Granite (T-5)

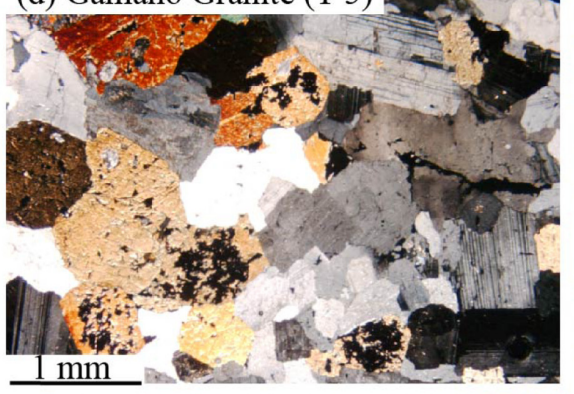

(g) Biotite schist \& con qtz-veins 2 zes

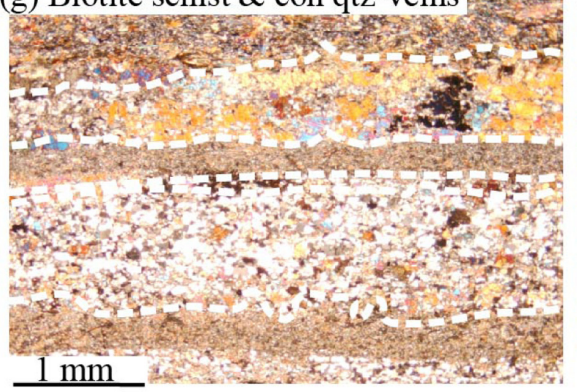

(b) Iwakuni Granite (T-7)
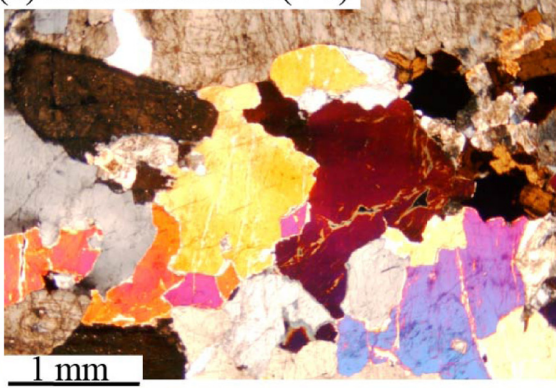

(e) Rokuroshi granite porphyry (T-1)

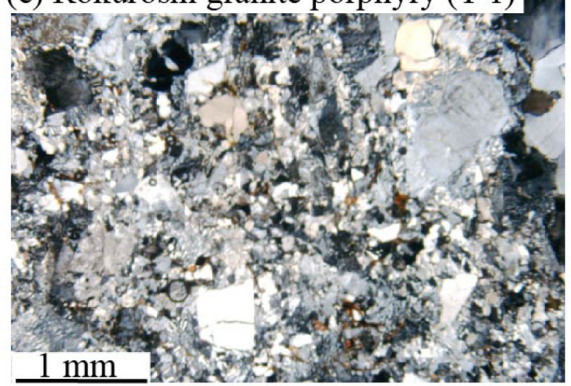

(h) Biotite schist \& dis qtz-veins

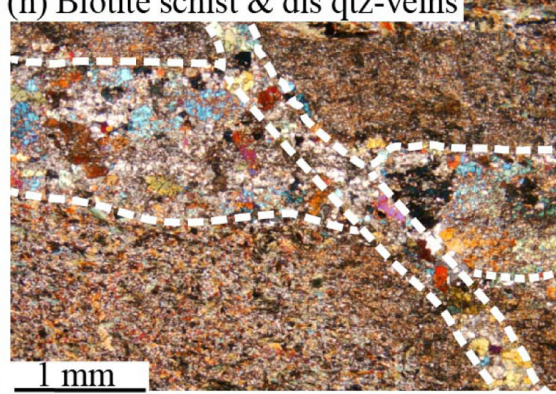

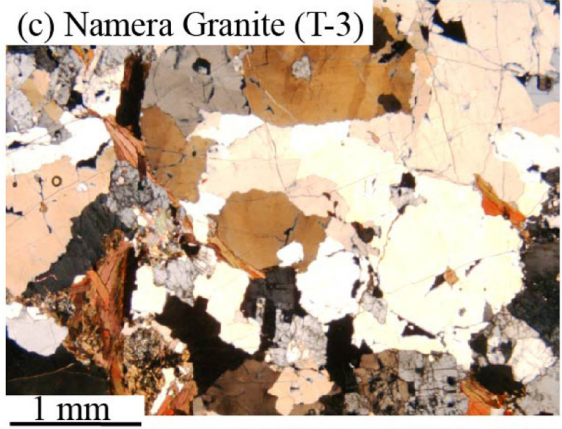

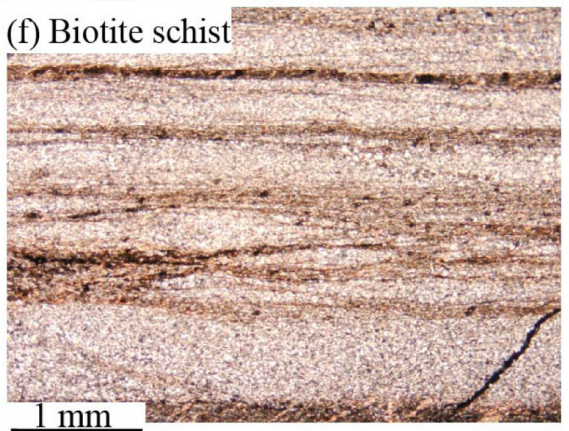

(i) Siliceous schist \& dis qtz-veins

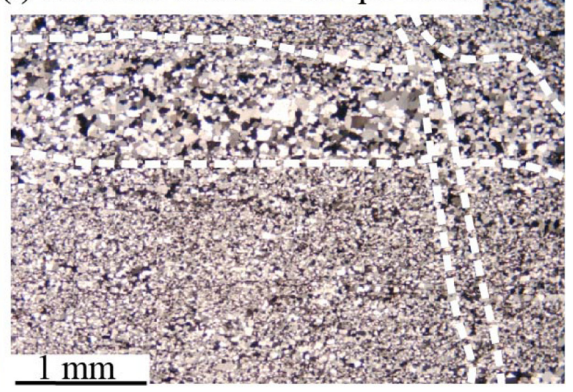

Figure 3. Photomicrographs displaying the textural features of granites from San-yo belt (a-b), Ryoke belt (c-d), and a granite porphyry dike (e). Photomicrographs displaying textural features of the Ryoke metamorphic rocks $(f-h)$ biotite schist, (i) siliceous schist, and foliation-parallel and foliation-normal quartz veins (g-i).

the Ryoke belt granites (Figs. 3c and 3d), Rokuroshi granite porphyry (Fig. 3e), biotite and siliceous schists and quartz veins (Fig. 3f-i) are presented as textural features. All the granites are medium to coarsegrained, displaying porphyritic textures. They are composed of Potassium feldspar $(\mathrm{Kfs})$, quartz $(\mathrm{Qtz})$, plagioclase $(\mathrm{Pl})$, biotite $(\mathrm{Bt})$, muscovite (Ms), and hornblende ( $\mathrm{Hbl})$, opaque minerals, and accessory apatite, monazite, and zircon. The Rokuroshi granite porphyry (Fig. $3 \mathrm{e}$ ) is characterized by fine-grained Qtz, $\mathrm{Kfs}$, and $\mathrm{Pl}$, with minor $\mathrm{Bt}$ and opaque minerals. A few Kfs phenocrysts are present surrounded by fine-grained matrix.

Biotite and siliceous schists are dominantly composed of Qtz, Bt, chlorite, and well-foliated, fine-grained matrix (Figs. 3f-3i). Moreover, biotite and siliceous schists contain numerous quartz veins which occur as foliation-parallel (marked as con qtz-veins on Fig. 3g) and foliation-normal (marked as dis qtz-veins on Figs. $3 \mathrm{~h}$ and $3 \mathrm{i}$ ) when viewed at outcrop-scale (Fig. 2a).

\section{Analytical Methods}

Quartz crystals (apparently clean with no visible inclusions; Fig. 4)

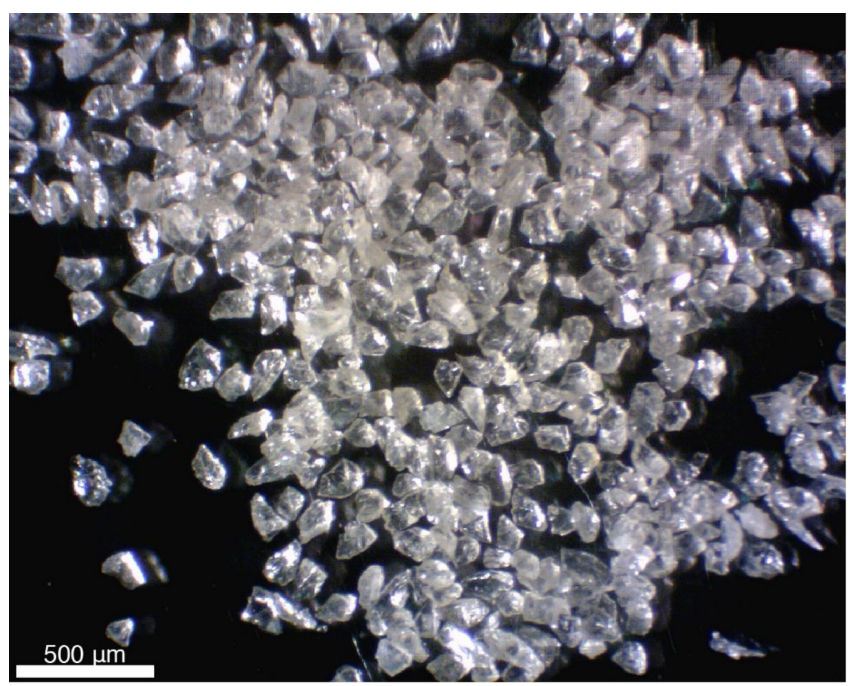

Figure 4. Photomicrograph of representative quartz separates, used for oxygen isotope analysis.

from six crushed granitic samples (two from San-yo belt, three from Ryoke belt, and one from the Rokuroshi granite porphyry) were separated and analyzed for $\delta^{18} \mathrm{O}$ values, defined as $\left[\left({ }^{18} \mathrm{O} /{ }^{16} \mathrm{O}_{\text {sample }} \div{ }^{18} \mathrm{O} /\right.\right.$ 
Table 1. $\delta^{18} \mathrm{O}$ values of quartz and U-Pb and Hf-isotope data of granites, metamorphic rocks, and silicic veins in the Iwakuni area, SW Japan

\begin{tabular}{|c|c|c|c|c|c|c|c|c|c|}
\hline Sample & Locality & Type & $\begin{array}{l}\text { Latitude }\left(\mathrm{N}^{\circ}\right), \\
\text { Longitude }\left(\mathrm{E}^{\circ}\right)\end{array}$ & $\begin{array}{c}\text { Mineral } \\
\text { assemblage }\end{array}$ & $\delta^{18} \mathrm{O}$ & $\begin{array}{c}\delta^{18} \mathrm{O} \\
\text { (repeat) }\end{array}$ & $\begin{array}{c}\text { U-Pb age } \\
\text { (Ma) }\end{array}$ & $\begin{array}{c}1 \sigma \\
(\mathrm{Ma})\end{array}$ & $\begin{array}{c}\varepsilon_{\mathrm{Hf}}(\mathrm{t}) \\
\text { (range) }\end{array}$ \\
\hline \multicolumn{10}{|c|}{ Granites (San-yo belt) } \\
\hline $\mathrm{T}-7$ & Iwakuni Granite & granite & $\begin{array}{l}34^{\circ} 06^{\prime} 46^{\prime \prime} \mathrm{N} \\
132^{\circ} 11^{\prime} 00^{\prime \prime} \mathrm{E}\end{array}$ & Qtz, Pl, Kfs, Bt & 9.7 & & & & \\
\hline $\mathrm{T}-2$ & Shimokuhara Granite & granite & $\begin{array}{l}34^{\circ} 06^{\prime} 07^{\prime \prime} \mathrm{N} \\
132^{\circ} 08^{\prime} 03^{\prime \prime} \mathrm{E}\end{array}$ & Qtz, Pl, Kfs, Bt & 12.4 & 12.9 & 103.8 & \pm 1.5 & $(-18.1$ to -1.4$)$ \\
\hline \multicolumn{10}{|c|}{$\overline{\text { Granites (Ryoke belt) }}$} \\
\hline T-6 & Kibe Granite & granite & $\begin{array}{l}34^{\circ} 01^{\prime} 41^{\prime \prime} \mathrm{N} \\
132^{\circ} 09^{\prime} 44^{\prime \prime} \mathrm{E}\end{array}$ & Qtz, Pl, Kfs, Bt & 11.3 & & & & \\
\hline $\mathrm{T}-3$ & Namera Granite & granite & $\begin{array}{l}34^{\circ} 03^{\prime} 15^{\prime \prime} \mathrm{N} \\
132^{\circ} 08^{\prime} 37^{\prime \prime} \mathrm{E}\end{array}$ & Qtz, Pl, Kfs, Bt, Ms & 12.5 & 12.4 & 106.3 & \pm 1.6 & $(-4.8$ to -2.8$)$ \\
\hline $\mathrm{T}-5$ & Gamano Granodiorite & granodiorite & $\begin{array}{l}34^{\circ} 02^{\prime} 13^{\prime \prime} \mathrm{N} \\
132^{\circ} 12^{\prime} 02^{\prime \prime} \mathrm{E}\end{array}$ & Qtz, Pl, Kfs, Hbl, Bt & 11.3 & 11.5 & 92.3 & \pm 2.6 & $(-0.9$ to +1.1$)$ \\
\hline \multicolumn{10}{|c|}{ Granite porphyry } \\
\hline $\mathrm{T}-1$ & $\begin{array}{l}\text { Rokuroshi } \\
\text { porphyry dike }\end{array}$ & granite porphyry & $\begin{array}{l}34^{\circ} 06^{\prime} 36^{\prime \prime} \mathrm{N} \\
132^{\circ} 09^{\prime} 14^{\prime \prime} \mathrm{E}\end{array}$ & Qtz, Pl, Kfs, Bt & 11.4 & 11.0 & 92.5 & \pm 1.6 & $(-0.3$ to 0.0$)$ \\
\hline \multicolumn{10}{|c|}{ Metamorphic rocks } \\
\hline OA-46(H) & Biotite schist & & $\begin{array}{l}34^{\circ} 06^{\prime} 22^{\prime \prime} \mathrm{N} \\
132^{\circ} 09^{\prime} 57^{\prime \prime} \mathrm{E}\end{array}$ & Qtz, Bt, Pl & 17.3 & & $102(?)$ & & \\
\hline OA-180(H) & Biotite schist & & $\begin{array}{l}34^{\circ} 06^{\prime} 39^{\prime \prime} \mathrm{N} \\
132^{\circ} 09^{\prime} 57^{\prime \prime} \mathrm{E}\end{array}$ & Qtz, Bt, Pl & 15.1 & & $102(?)$ & & \\
\hline B-5 & Siliceous schist & & $\begin{array}{l}34^{\circ} 06^{\prime} 39^{\prime \prime} \mathrm{N} \\
132^{\circ} 09^{\prime} 57^{\prime \prime} \mathrm{E}\end{array}$ & Qtz, Ms, Pl & 16.6 & & $90(?)$ & & \\
\hline OA-77 & Siliceous schist & & $\begin{array}{l}34^{\circ} 06^{\prime} 32^{\prime \prime} \mathrm{N} \\
132^{\circ} 9^{\prime} 21^{\prime \prime} \mathrm{E}\end{array}$ & Qtz, Ms, Pl & 17.8 & & $90(?)$ & & \\
\hline OA-182(H) & Siliceous schist & & $\begin{array}{l}34^{\circ} 06^{\prime} 39^{\prime \prime} \mathrm{N} \\
132^{\circ} 09^{\prime} 57^{\prime \prime} \mathrm{E}\end{array}$ & Qtz, Ms, Pl & 16.4 & & $90(?)$ & & \\
\hline $\mathrm{T}-9(\mathrm{H})$ & Siliceous schist & & $\begin{array}{l}34^{\circ} 06^{\prime} 39^{\prime \prime} \mathrm{N} \\
132^{\circ} 09^{\prime} 57^{\prime \prime} \mathrm{E}\end{array}$ & Qtz, Ms, Pl & 17.1 & & $90(?)$ & & \\
\hline Quartz-veins & Host-rock & & & & & & inferred & age & \\
\hline OA-180(V) & Biotite schist & foliation-parallel & $\begin{array}{l}34^{\circ} 06^{\prime} 39^{\prime \prime} \mathrm{N} \\
132^{\circ} 09^{\prime} 57^{\prime \prime} \mathrm{E}\end{array}$ & Qtz & 16.6 & & $<90(?)$ & & \\
\hline OA-46(V) & Biotite schist & foliation-normal & $\begin{array}{l}34^{\circ} 06^{\prime} 22^{\prime \prime} \mathrm{N} \\
132^{\circ} 09^{\prime} 57^{\prime \prime} \mathrm{E}\end{array}$ & Qtz & 17.3 & & $<90(?)$ & & \\
\hline OA-182(V) & Siliceous schist & foliation-normal & $\begin{array}{l}34^{\circ} 06^{\prime} 39^{\prime \prime} \mathrm{N} \\
132^{\circ} 09^{\prime} 57^{\prime \prime} \mathrm{E}\end{array}$ & Qtz & 17.2 & & $<90(?)$ & & \\
\hline $\mathrm{T}-8(\mathrm{~V})$ & Siliceous schist & foliation-normal & $\begin{array}{l}34^{\circ} 06^{\prime} 39^{\prime \prime} \mathrm{N} \\
132^{\circ} 09^{\prime} 57^{\prime \prime} \mathrm{E}\end{array}$ & Qtz & 17.6 & & $<90(?)$ & & \\
\hline $\mathrm{T}-9(\mathrm{~V})$ & Siliceous schist & foliation-normal & $\begin{array}{l}34^{\circ} 06^{\prime} 39^{\prime \prime} \mathrm{N} \\
132^{\circ} 09^{\prime} 57^{\prime \prime} \mathrm{E}\end{array}$ & Qtz & 17.6 & & $<90(?)$ & & \\
\hline
\end{tabular}

Sample labels similar but with labels "H" mean host rock and with "V" mean silicic veins from the same locality. Values of the U-Pb age and $\varepsilon_{\mathrm{Hf}}(\mathrm{t})$ of granite samples are obtained from zircons as reported in Mateen et al. (2019). Source for the age of metamorphic rocks is provided in main text. Age values for quartz veins (shown in bold italic fonts) are inferred and assumed to be younger than the host rocks due to their cross-cutting nature.

$\left.\left.{ }^{16} \mathrm{O}_{\mathrm{STD}}\right)-1\right] \times 1000$ in which the STD is Vienna Standard Mean Ocean Water (VSMOW) using the conventional $\mathrm{BrF}_{5}$ Fluorination technique after Clayton and Mayeda (1963). In order to understand the effect of granites on metamorphic rocks or vice versa, we also analyzed quartz crystals that were separated from two biotite schist samples and four siliceous schist samples from the Ryoke metamorphic belt. Furthermore, to understand the source of fluids that formed these veins, we analyzed quartz crystals that were separated from the foliation-parallel and foliation-normal quartz veins within the biotite and siliceous schists (see details in Table 1). The analyses were conducted at the Institute of Earth Sciences, Academia Sinica, Taiwan using the Finnigan MAT 252 mass spectrometer. The precision of individual analyses of the NBS-28 quartz standard ( $+9.6 \%$ ) and unknown samples (this study) was better than $\pm 0.2 \%$. The results of ${ }^{18} \mathrm{O} /{ }^{16} \mathrm{O}$ ratios are reported in per mil "\%" relative to the VSMOW. Petrographic summary and $\delta^{18} \mathrm{O}$ values are presented in Table 1. Whole-rock major oxides (wt.\%.) and trace element contents (ppm) were analyzed on fused glass beads, prepared from $0.4 \mathrm{~g}$ sample powder mixed with $4 \mathrm{~g}$ of lithium tetraborate, using the X-Ray Fluorescence spectrometer (Rigaku ZSX-100e) housed at Kagoshima University's Division of Instrumental Analysis Research Support Center and the results are shown in Table 2. During XRF analysis 14 standard reference materials of the GSJ (JA-1, JA-2, JA-3, JB-1a, JB-2, JB-3, JF-1, JF-2, JG-1, JG-1a, JG-2, JG-3, JGb-1, and JP-1; Imai et al., 1995) were used for 
Table 2. Major oxides (wt.\%) and trace element contents (ppm) of the granites, and metamorphic rocks

\begin{tabular}{|c|c|c|c|c|c|c|c|c|c|c|}
\hline Rock & T-2 & T-2r & T-7 & T-3 & $\mathrm{T}-3 \mathrm{r}$ & T-6 & T-5 & T-1 & OA-46 & OA-77 \\
\hline Sample & Shimokuha & ca Granite & $\begin{array}{l}\text { Iwakuni } \\
\text { Granite }\end{array}$ & Namera & Granites & $\begin{array}{c}\text { Kibe } \\
\text { Granites }\end{array}$ & $\begin{array}{c}\text { Gamano } \\
\text { Granodiorite }\end{array}$ & $\begin{array}{l}\text { Rukoroshi } \\
\text { granite porphry }\end{array}$ & $\begin{array}{l}\text { Biotite } \\
\text { schist }\end{array}$ & $\begin{array}{c}\text { Siliceous } \\
\text { schist }\end{array}$ \\
\hline $\mathrm{SiO}_{2}$ (wt.\%) & 73.76 & 73.86 & 73.67 & 73.81 & 73.94 & 75.14 & 61.32 & 76.40 & 65.46 & 68.65 \\
\hline $\mathrm{TiO}_{2}$ & 0.20 & 0.20 & 0.27 & 0.24 & 0.23 & 0.25 & 0.32 & 0.05 & 1.10 & 0.78 \\
\hline $\mathrm{Al}_{2} \mathrm{O}_{3}$ & 14.53 & 14.52 & 13.40 & 14.32 & 14.31 & 15.16 & 16.70 & 12.89 & 14.07 & 16.40 \\
\hline $\mathrm{FeO}(\mathrm{t})$ & 2.11 & 2.10 & 2.64 & 2.38 & 2.37 & 1.85 & 6.37 & 1.18 & 7.46 & 5.56 \\
\hline $\mathrm{MnO}$ & 0.06 & 0.06 & 0.04 & 0.05 & 0.05 & 0.02 & 0.11 & 0.02 & 0.09 & 0.13 \\
\hline $\mathrm{MgO}$ & 0.49 & 0.47 & 0.53 & 0.76 & 0.76 & 0.57 & 2.41 & 0.15 & 3.41 & 2.01 \\
\hline $\mathrm{CaO}$ & 1.71 & 1.71 & 1.84 & 1.75 & 1.74 & 1.18 & 7.15 & 0.80 & 2.86 & 0.92 \\
\hline $\mathrm{Na}_{2} \mathrm{O}$ & 3.04 & 3.01 & 3.73 & 3.26 & 3.16 & 1.94 & 4.06 & 3.58 & 2.32 & 1.79 \\
\hline $\mathrm{K}_{2} \mathrm{O}$ & 4.04 & 4.01 & 3.84 & 3.37 & 3.36 & 3.79 & 1.26 & 4.91 & 2.95 & 3.65 \\
\hline $\mathrm{P}_{2} \mathrm{O}_{5}$ & 0.06 & 0.06 & 0.06 & 0.07 & 0.07 & 0.10 & 0.29 & 0.01 & 0.28 & 0.11 \\
\hline Total & 100.00 & 100.00 & 100.00 & 100.00 & 100.00 & 100.00 & 100.00 & 100.00 & 100.00 & 100.00 \\
\hline $\mathrm{Cr}(\mathrm{ppm})$ & 7.899 & 6.178 & 2.632 & 15.858 & 14.376 & bdl & 16.391 & 0.949 & 114.133 & 73.137 \\
\hline $\mathrm{Ni}$ & 34.104 & 36.226 & 28.167 & 36.118 & 38.109 & 1.428 & 6.683 & 37.254 & 84.816 & 43.550 \\
\hline V & 11.679 & 7.832 & 20.016 & 18.422 & 23.128 & 13.507 & 168.300 & bdl & 189.318 & 127.025 \\
\hline $\mathrm{Cl}$ & 96 & 91 & 90 & 91 & 115 & 103 & 175 & 85 & 106 & 77 \\
\hline $\mathrm{Hf}$ & 4 & 4 & 4 & 4 & 3 & 3 & 3 & 4 & 3 & 3 \\
\hline $\mathrm{Ta}$ & 2 & 2 & 2 & 2 & 2 & 1 & 1 & 2 & 1 & 1 \\
\hline $\mathrm{Zr}$ & 86.29 & 85.76 & 135.11 & 92.50 & 92.39 & 115.64 & 215.80 & 61.54 & 119.29 & 130.21 \\
\hline $\mathrm{Nb}$ & 12.312 & 12.046 & 11.299 & 12.128 & 12.205 & 10.008 & 8.977 & 10.614 & 9.266 & 11.448 \\
\hline Y & 29.198 & 29.065 & 27.424 & 28.893 & 28.993 & 27.010 & 29.824 & 27.304 & 23.004 & 27.480 \\
\hline $\mathrm{Sr}$ & 176.515 & 174.912 & 215.156 & 178.745 & 179.203 & 114.423 & 309.822 & 108.676 & 230.222 & 104.702 \\
\hline $\mathrm{Rb}$ & 125.197 & 124.135 & 97.033 & 118.744 & 118.571 & 142.596 & 39.608 & 101.355 & 80.171 & 109.819 \\
\hline $\mathrm{Zn}$ & 77 & 77 & 84 & 77 & 80 & 50 & 88 & 60 & 145 & 125 \\
\hline $\mathrm{Ba}$ & 466.122 & 483.018 & 1277.687 & 386.792 & 440.853 & 440.257 & 270.248 & 709.349 & 668.450 & 695.639 \\
\hline $\mathrm{Ce}$ & 42 & 34 & 83 & 38 & 38 & 41 & 32 & 47 & 69 & 69 \\
\hline Th & 11 & 11 & 10 & 11 & 11 & 8 & 6 & 11 & 6 & 9 \\
\hline U & 3 & 3 & 3 & 3 & 3 & 2 & 2 & 3 & 2 & 2 \\
\hline $\mathrm{Nd}$ & 19 & 17 & 20 & 21 & 16 & 10 & 33 & 13 & 23 & 25 \\
\hline $\mathrm{Ga}$ & 18 & 18 & 18 & 18 & 18 & 17 & 17 & 18 & 17 & 17 \\
\hline $\mathrm{Pb}$ & 28 & 28 & 26 & 28 & 28 & 19 & 17 & 30 & 22 & 23 \\
\hline $\mathrm{La}$ & 16 & 18 & 17 & 14 & 24 & 2 & 15 & 14 & 29 & 31 \\
\hline $\mathrm{D}_{\mathrm{Zr}}^{\text {zircon/melt }}$ & 5767 & 5803 & 3683 & 5380 & 5386 & 4303 & 2306 & 8087 & 4172 & 3822 \\
\hline $\mathbf{T}_{\mathrm{Zr}_{-} \text {Sat }}$ & 745 & 746 & 766 & 752 & 753 & 796 & 753 & 710 & 761 & 813 \\
\hline
\end{tabular}

Foot note to table 2: Zr-saturation temperature $\left({ }^{\circ} \mathrm{C}\right)$ values are calculated after the method of Watson and Harrison (1983) and the calculation method is reported in Rehman et al. (2021). Abbreviation "bdl" means below the detection limit.

analytical calibrations and matrix corrections. The detection limits of the XRF during the analyses were $0.01 \%$ for major elements, 0.001 ppm for trace elements such as $\mathrm{Ba}, \mathrm{Cr}, \mathrm{Nb}, \mathrm{Ni}, \mathrm{Rb}, \mathrm{Sr}, \mathrm{V}, \mathrm{Y}$, and $\mathrm{Zr}$, and 1 ppm for $\mathrm{U}, \mathrm{Cl}, \mathrm{Ga}, \mathrm{Hf}$, Ta, Ce, Th, Pb, Zn, Nd and La.

\section{Results}

\section{Granites of the San-yo Belt}

Quartz grains from the Shimokuhara Granite (marked T-2 on Fig. 1b) showed $\delta^{18} \mathrm{O}$ values of $12.4-12.9 \%$ (duplicate analysis). The Shimoku- hara Granite yielded $\mathrm{SiO}_{2}$ contents of 73.76-73.86 wt.\% (duplicate analysis; Table 2). Quartz grains from the Iwakuni Granite (marked T-7 on Fig. 1b) showed $\delta^{18} \mathrm{O}$ value of $9.7 \%$. Whole-rock XRF analysis showed $\mathrm{SiO}_{2}$ contents of 73.67 wt.\% (Table 2) for the Iwakuni Granite.

\section{Granites of the Ryoke Belt}

Quartz grains from the samples of Namera and Kibe Granites (marked T-3 and T-6 on Fig. 1b), respectively, showed $\delta^{18} \mathrm{O}$ values of 12.5 and $11.3 \%$. These values are relatively higher than the values of quartz crystallized from typical I-type granitic magma ca. 5-8\%o but 
show overlap to those found in the S-type granitic magmas ca. 9-12\%o (Harris et al., 1997; Valley et al., 2005). Whole-rock major oxides obtained from the XRF analysis yielded $\mathrm{SiO}_{2}$ contents of 73.81-73.94 wt.\% (duplicate analysis; Table 2) for the Namera Granite and 75.14 wt.\% for the Kibe Granite. Quartz grains in the Gamano Granodiorite (marked T-5 on Fig. 1b) showed $\delta^{18} \mathrm{O}$ value of $9.7 \%$, slightly higher than the values of typical I-type granite but display lower $\mathrm{SiO}_{2}$ contents for the whole-rock (ca. $61.32 \mathrm{wt} . \%$; Table 2).

\section{Granite Porphyry Dike}

Quartz grains from a dike that belongs to the Rokuroshi granite porphyry dike swarm (marked T-1 on Fig 1 b) showed $\delta^{18} \mathrm{O}$ values of 11.0 and $11.4 \%$ (duplicate analysis) and the $\mathrm{SiO}_{2}$ contents of $76.40 \mathrm{wt} . \%$ (Table 2).

\section{The Ryoke Metamorphic Belt}

Quartz grain in two samples from biotite schist (OA-46H and OA$180 \mathrm{H}$, marked on Figs. $2 \mathrm{a}$ and $2 \mathrm{~b}$ ) showed $\delta^{18} \mathrm{O}$ values of 15.1 and $17.3 \%$, respectively. Whole-rock major oxides obtained from the XRF analysis showed $\mathrm{SiO}_{2}$ contents of 65.46 wt.\% (Table 2) from a biotite schist sample. Quartz grains from four samples of siliceous schist (B5, OA-77, OA-182H, and T-9H, Figs. 2a and 2b) exhibited a range of $\delta^{18} \mathrm{O}$ values between 16.4 and $17.8 \%$. Whole-rock major oxides obtained from the XRF analysis showed $\mathrm{SiO}_{2}$ contents of 68.65 wt.\% (Table 2) from a siliceous schist sample.

\section{Quartz Veins in the Ryoke Metamorphic Belt}

Similar results of $\delta^{18} \mathrm{O}$ values (16.6-17.6\%o, $\mathrm{n}=5$ ) were obtained from quartz crystals taken from veins that exist within the biotite and siliceous schists (Figs. 2a and 2b, and shown in Table 1). It is worthy to note that the $\delta^{18} \mathrm{O}$ values of quartz veins, despite of their different structural occurrence such as foliation-parallel and/or foliation-normal, exhibited a very narrow range $<1 \%$.

\section{Interpretations of Results}

Numerous authors have discussed the occurrence, emplacement order, and magma genesis of the granitoids of the Inner Zone, based on detailed structural relationships in the field, petrographic observations on individual granitic bodies, and geochemical and geochronological results (e.g., Kojima, 1953; Okamura, 1957, 1960; Koide, 1958; Kawano and Ueda, 1966; Shigeno and Yamaguchi, 1976; Hayasaka et al., 1983; Higashimoto et al., 1983; Okano and Honma, 1983; Kagami et al., 1992; Ikeda, 1993, 1998; Owada et al., 1995; Suzuki et al., 1996; Suzuki and Adachi, 1998; Herzig et al., 1998; Nakajima et al., 1993; Ishihara and Matsuhisa, 2002; Ishihara and Chappell, 2007; Akasaki et al., 2013, 2015; Skrzypek et al., 2016, 2018; Nakajima, 2018; Mateen et al., 2019 and references therein). In the forthcoming sections, a discussion is presented on the magma origin, effects of the metasedimentary sources on the magmatic rocks, and the role of fluids that precipitated the late-stage quartz veins.

\section{Origin of the Granitic Magma}

The analyzed quartz crystals from granites from the Sanyo-yo and Ryoke belts and the Rokuroshi granite porphyry dike show relatively higher $\delta^{18} \mathrm{O}$ values than those reported for the magmas that form Itype granites having a whole-rock range between +5 and $+8 \%$ but fall within the range of whole-rock for the S-type granites (ca. +9 to $+12 \%$ ) (Valley et al., 2005; Hoefs, 2009). Although, we did not analyze wholerock samples for $\delta^{18} \mathrm{O}$ values, those can be empirically calculated for the granitic magma through the $\delta^{18} \mathrm{O}$ values of the analyzed quartz grains (i.e., whole-rock $\delta^{18} \mathrm{O}$ values are $1-2 \%$ lower than the quartz values, as proposed by Harris et al., 1997). Generally, $\delta^{18} \mathrm{O}$ values of whole-rock samples from I- or S-type granitic magmas may provide useful constraints on the genesis of parental magma however wholerock data may be subject to post-magmatic changes or sub-solidus alteration that will significantly affect oxygen isotope ratios as pointed out by Harris et al. (1997). In contrast, oxygen isotope data of purified quartz grains provide better constraints of the original magma from which the grains crystallized. Therefore, oxygen isotope data of quartz grains, combined with $\mathrm{U}-\mathrm{Pb}$ zircon age data, are used to understand the origin of granite magma. The $\delta^{18} \mathrm{O}$ values for the quartz samples (measured in this study) against U-Pb zircon ages (Fig. 5a) plot mainly in the S-type field and significantly above the I-type granites field. Values from the analyzed quartz in this study are comparatively higher (though by a very small amount) in the Shimokuhara and Namera Granites (samples T-2 and T-3) than in the Iwakuni, Kibe, and Gamano granites (samples T-7, T-6, and T-5) and the Rokuroshi granite porphyry (sample T-1). The enrichment of $\delta^{18} \mathrm{O}$ values suggests a common parental magma for the granites in the San-yo and Ryoke belts, that was likely derived from hydrothermally altered crustal precursors before their subduction. Ishihara (1977) suggested the ${ }^{18} \mathrm{O}$ enrichment in Ryoke belt granites was due to the assimilation of sedimentary rocks into the granites. Our data also indicate that assimilation of the altered precursors with the felsic magma was the major factor to form granites with slightly elevated $\delta^{18} \mathrm{O}$ values; however, the Iwakuni Granite (sample T-7) was the least chemically modified and retained the lowest $\delta^{18} \mathrm{O}$ values. Although there is no textural evidence among the studied granites that can mark the chemical difference, the investigated granites plot in the peraluminous field (Fig. 6a) in the $\mathrm{A} / \mathrm{NK}$ (molecular $\mathrm{Al}_{2} \mathrm{O}_{3} / \mathrm{Na}_{2} \mathrm{O}+\mathrm{K}_{2} \mathrm{O}$ ) vs $\mathrm{A} / \mathrm{CNK}$ (molecular $\mathrm{Al}_{2} \mathrm{O}_{3} / \mathrm{CaO}+\mathrm{K}_{2} \mathrm{O}+\mathrm{Na}_{2} \mathrm{O}$ ) diagram of Shand (1943), indicating their genesis from partial melting of the crustal source which is also affirmed by the ${ }^{18} \mathrm{O}$ enrichment in these rocks (Clemens et al., 2010). On the $\mathrm{FeO} /\left(\mathrm{FeO}+\mathrm{MgO}\right.$ ) vs. $\mathrm{SiO}_{2}$ diagram (Frost et al., 2001; Frost and Frost, 2008), the analyzed granites plot in the magnesian field except for the porphyry dike sample, which plots in the ferroan field and A-type granite field (Fig. 6b). Similarly, on the $\mathrm{Na}_{2} \mathrm{O}+\mathrm{K}_{2} \mathrm{O}-\mathrm{CaO}$ vs. $\mathrm{SiO}_{2}$ diagram (Frost et al., 2001; Frost and Frost, 2008; also revisited in Bonin et al., 2020), the analyzed granite samples plot in transition of calcic and calc-alkalic fields whereas the porphyry dike sample plots in the alkali-calcic field (Fig. 6c). Other major and trace element contents of the granite samples, when plotted against the molar amount of $\mathrm{Fe}+\mathrm{Mg}$ (referred as maficity by Clemens et al., 2010), show positive correlations with $\mathrm{Ti}$ and $\mathrm{Zr}$, and negative correlations with $\mathrm{A} / \mathrm{CNK}, \mathrm{K}$, and $\mathrm{SiO}_{2}$, respectively (Figs. 7a-7d). This also confirms the involvement of crustal component in the formation of granitic magmas. To 

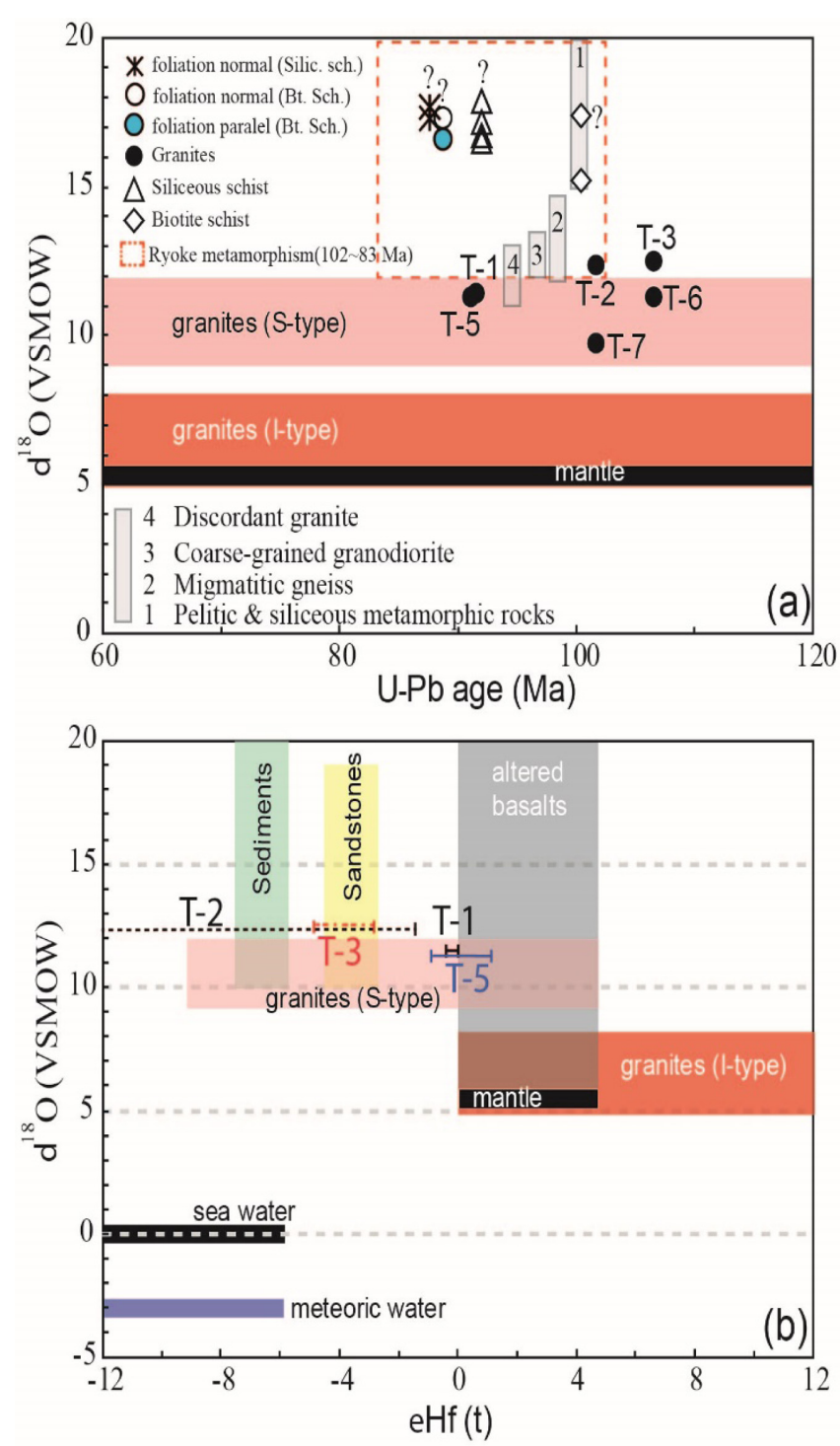

Figure 5. (a) Values of $\delta^{18} O$ of quartz from the analyzed samples plotted against $U-P b$ age of zircons from the same samples, reported in Mateen et al. (2019). Values of $\delta^{18} O$ for I- and S-type granites and other rock types are after Valley et al. (2005 and references therein). Vertical boxes with numbers (1-4) show $\delta^{18} O$ values of quartz from granites and metamorphic rocks from the Iwakuni area reported by Honma and Sakai (1975). Age-data of the vein samples is unknown (question-marked) but based on their structural relationship and crosscutting of the schists, we plotted them at the minimum age limit $(<90 \mathrm{Ma})$ of the Ryoke metamorphism. (b) Values of $\delta^{18} \mathrm{O}$ of quartz from the analyzed granite samples plotted against the range of $\varepsilon_{H f}(t)$ values obtained among the analyzed zircons in the same samples, reported in Mateen et al. (2019). Fields for other rock types shown on the plot are based from the data in past publications (Valley et al., 2005 and references therein).

estimate temperature of magmatic crystallization of the granitic samples, an independent thermometer (Zr-saturation thermometry after Watson and Harrison, 1983) was applied that yielded temperature values in the range from 745 to $766^{\circ} \mathrm{C}$ for the San-yo belt granites and from 752 to $796^{\circ} \mathrm{C}$ for the Ryoke belt granites whereas $710^{\circ} \mathrm{C}$ was obtained from the Rukoroshi granite porphyry dike sample (Table 2). The Zr-saturation thermometry results are 50 to $100^{\circ} \mathrm{C}$ higher than the
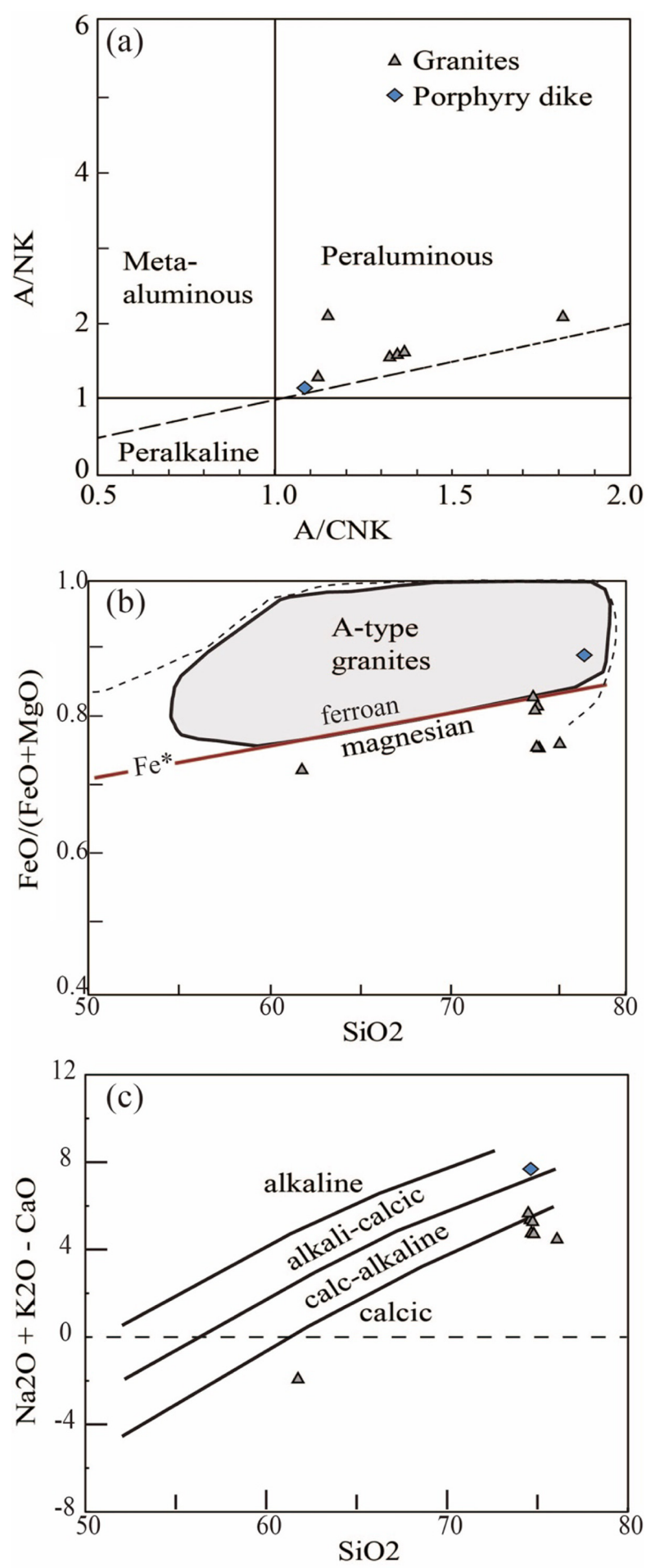

Figure 6. Binary plots of major element contents for whole-rock analyses of the studied samples. (a) Data for granites and porphyry dike plot in the peraluminous field according to the $A / N K$ (molecular $\mathrm{Al}_{2} \mathrm{O}_{3} / \mathrm{Na}_{2} \mathrm{O}+\mathrm{K}_{2} \mathrm{O}$ ) vs. $\mathrm{A} / \mathrm{CNK}$ (molecular $\mathrm{Al}_{2} \mathrm{O}_{3} / \mathrm{CaO}+\mathrm{K}_{2} \mathrm{O}+\mathrm{Na}_{2} \mathrm{O}$ ) plot (Shand, 1943), (b) granites show magnesian type granites when the data were plotted in the $\mathrm{FeO} /(\mathrm{FeO}+\mathrm{MgO})$ vs. $\mathrm{SiO}_{2}$ diagram by Frost et al. (2001), and revised in Frost and Frost (2008); and the porphyry dike sample shows ferroan A-type granite, (c) similarly, data for granites plot in calcic to calc-alkaline fields whereas the porphyry dike sample shows alkali-calcic composition upon plotting them in the $\mathrm{Na}_{2} \mathrm{O}+\mathrm{K}_{2} \mathrm{O}-\mathrm{CaO}$ vs. $\mathrm{SiO}_{2}$ (also termed as $\mathrm{MALI}$ ) diagram by Frost et al. (2001), and revised in Frost and Frost (2008). 

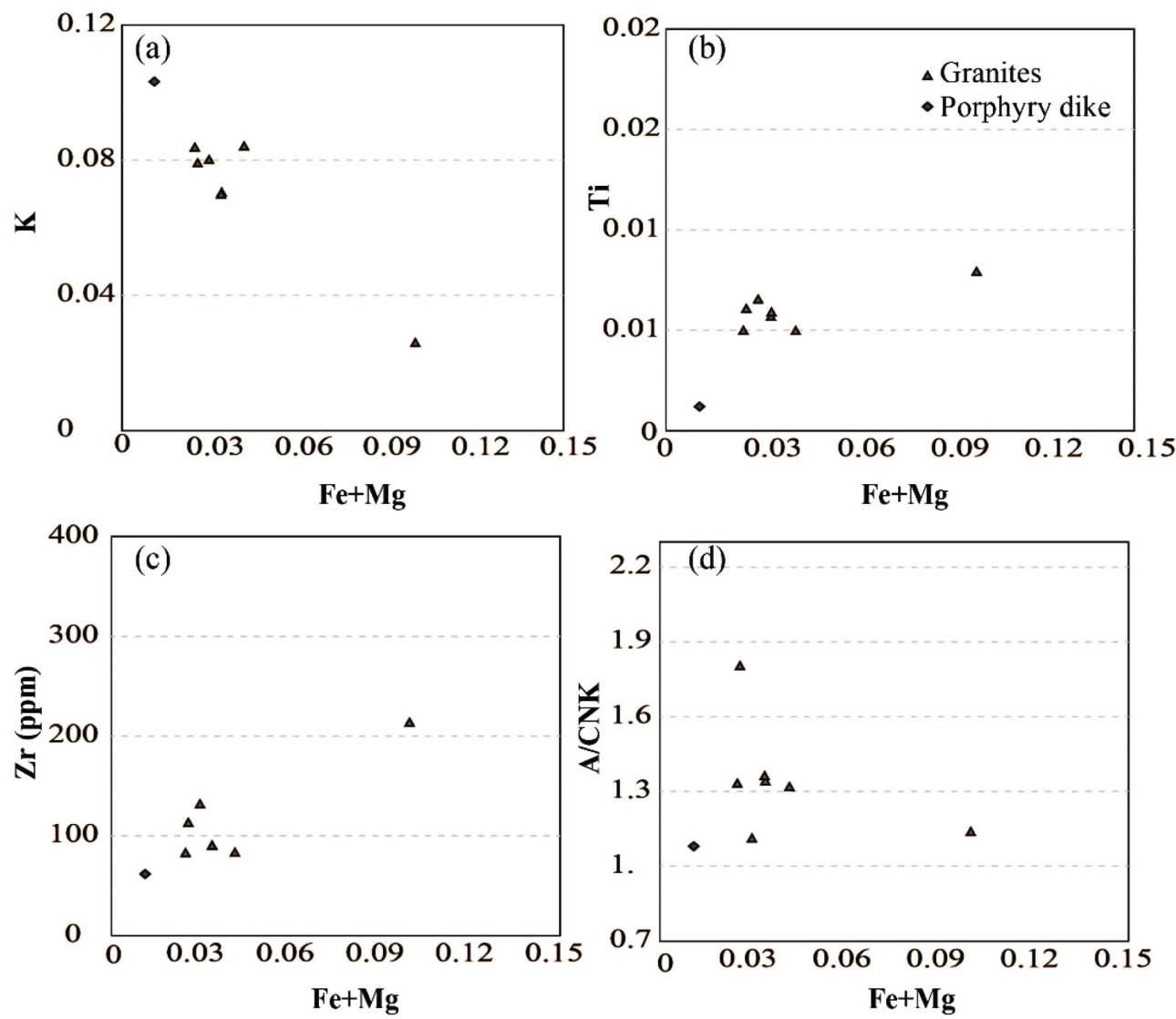

Figure 7. Whole-rock major and trace element data is also plotted against the maficity (molar amount of Fe+Mg as proposed by Clemens et al., 2010) in which the data show negative linear trends for $K$ (a), and positive linear trends for $T i(b), Z r(c)$, and A/CNK (d), indicating partial melting of the crust to form the granites.

values reported by Honma and Sakai (1975), showing a range between 600 to $700^{\circ} \mathrm{C}$ that were calculated from the oxygen isotope fractionation among the coexisting minerals in those granites. Earlier studies (Matsuhisa et al., 1972; Honma and Sakai, 1975; Kagami et al., 1992; Ishihara and Matsuhisa, 2002) interpreted the relatively higher $\delta^{18} \mathrm{O}$ values $(+10.0$ to $+13.2 \%)$ in granites located within the metamorphic zones of the Ryoke belt as being due to the extensive interaction of ${ }^{18} \mathrm{O}$-rich aqueous fluids derived from the metasedimentary source whereas the lower $\delta^{18} \mathrm{O}$ values $(+7.9$ to $+9.8 \%$ ) in I-type granites from the non-metamorphic zone resulted from the local isotopic exchange between granitic magma and the surrounding material. For comparison, the oxygen isotope data by Honma and Sakai (1975) for quartz samples from granites in the San-yo and Ryoke belts and surrounding metamorphic rocks (numbered from 1 to 4 ) are plotted in Figure 5a, the results are consistent with those obtained in this study. Honma and Sakai (1975) postulated that the interaction of granitic magma with the surrounding metasedimentary source resulted in elevating the $\delta^{18} \mathrm{O}$ values of the early-formed granites, however late-stage plutons do not show significant enrichment of ${ }^{18} \mathrm{O}$. This chemical variation can be attributed to a relatively less contaminated magma source (e.g., T-7). As pointed out by Ishihara and Matsuhisa (2002), quartz (resistant to hydrothermal alteration compared to the whole-rock) would likely retain unaltered $\delta^{18} \mathrm{O}$ values. The above authors observed a slight shift from a 1:1 trend when they plotted the data of quartz against wholerock (see Fig. 2 in Ishihara and Matsuhisa, 2002). The relatively lower $\delta^{18} \mathrm{O}$ values (ca. 5.9-10.6\%) in the magnetite series granites exposed in the North of San-yo belt were interpreted as having igneous source derived from the lower continental crust whereas relatively higher $\delta^{18} \mathrm{O}$ values in the ilmenite series granites from the San-yo belt (ca. 7.3-10.8\%o) and the Ryoke belt (ca. 11.6-12.0\%o) were interpreted to have formed from a mixed source, containing mafic enclaves, of primitive basaltic and Ryoke metasedimentary rocks.

Mateen et al. (2019) conducted U-Pb age and Hf isotope analysis on zircons from granites of the San-yo and Ryoke belts. Shimokuhara Granite (ca. 103.8 Ma) showed a range of $\varepsilon_{\mathrm{Hf}}(\mathrm{t})$ values from -1.4 to +0.7 in the analyzed zircons (among which a zircon grain displayed an exceptionally lower $\varepsilon_{\mathrm{Hf}}(\mathrm{t})$ value of -18.1 from an inherited detrital core of $144 \mathrm{Ma}$ ). The extremely negative $\varepsilon_{\mathrm{Hf}}(\mathrm{t})$ value confirm the presence of preexisting recycled crustal material (Vervoort et al., 1996, 1999, 2016; Kröner et al., 2014 and references therein) and cannot be related to the pristine magma that produced the San-yo granites. Zircons from Namera Granite (ca. 106.3 Ma), Gamano Granodiorite (ca. 92.3 Ma), and from the Rokuroshi granite porphyry (ca. 92.5 Ma) yielded $\varepsilon_{\mathrm{Hf}}(\mathrm{t})$ value of -2.8 to $-4.8,-0.9$ to +1.1 , and 0.0 to +0.3 , respectively. The slightly positive and near to zero $\varepsilon_{\mathrm{Hf}}(\mathrm{t})$ values suggest a relatively young and less-contaminated continental source whereas the negative $\varepsilon_{\mathrm{Hf}}(\mathrm{t})$ values indicate recycled crustal source. When $\delta^{18} \mathrm{O}$ values for quartz (along the vertical axis) were plotted against the $\varepsilon_{\mathrm{Hf}}$ (t) calculated values of zircons from the granite samples (excluding data from the inherited core) (not from quartz), the results fall in the 
field of S-type granites or slightly higher, clearly affirming the effect of metasedimentary precursors on the granitic magma (Fig. 5b).

The data obtained from this study show that most of the analyzed quartz crystals have $\delta^{18} \mathrm{O}$ values $>+9 \%$, reaching up to $+18 \%$, and which are higher than the $\delta^{18} \mathrm{O}$ values generally observed in the typical I-type granites, with some samples showing an overlap with the $\mathrm{S}$ type granite (Fig. 5a). The $\delta^{18} \mathrm{O}$ values of quartz in biotite and siliceous schists and foliation-parallel as well as foliation-normal veins are significantly higher than the values commonly observed in granites, and also indicate sedimentary source because sediments (such as shales, sandstones, or cherts show values $>12 \%$ ) acquire high $\delta^{18} \mathrm{O}$ values during their low-temperature sedimentation in seawater (Kolodny and Epstein, 1976; Eiler et al., 1998; Muehlenbachs, 1998; Hoefs, 2009). Our interpretation is indirectly supported by the high initial ${ }^{87} \mathrm{Sr} /{ }^{86} \mathrm{Sr}$ isotope ratios from some of the granites of the Inner Zone reported by Ishihara and Matsuhisa (2002), indicating the involvement of crustal component. The magma from which granitic bodies were crystallized was likely generated by the partial melting of the lower crust, partly including mantle-derived mafic component (as reported by Kagami et al., 1992), and also assimilated with the hydrothermally altered ${ }^{18} \mathrm{O}-$ and Sr-rich pre-existing sedimentary precursors. This interpretation is also supported by previous studies that were based on geochemical compositions of whole-rock and minerals (Czamanske et al., 1981). Those authors interpreted that granitoids of southwestern Japan were formed at lower crustal depths from mantle-derived magmas that partially melted the surrounding crustal precursors. Presence of xenoliths in some of those granitoids (e.g., Iwao, 1936, 1940; Okamura, 1957) and a large scatter in their Rb-Sr isotopic ratios (Okano and Honma, 1983; Kagami et al., 1992) additionally provide an evidence of assimilation of wall rocks (i.e., the Ryoke metamorphic rocks) that may have had a role in elevating the $\delta^{18} \mathrm{O}$ values in some of these granites. Ikeda (2004) proposed partial melting at the middle crustal levels that formed the granitoids and the coeval ages of gran- ites in the Ryoke belt and the neighboring metamorphosed schists/ gneisses support the above interpretation. The partial melting of crust possibly created the granitic magma which thermally affected the preexisting volcano sedimentary successions of the accretionary complexes in the surroundings however these interpretations were contradicted by several authors (e.g., Kawakami, 2004; Kawakami and Kobayashi, 2006) based on their results from the migmatites of the Ryoke metamorphic belt. In short, discrepancies still exist that need further investigation.

\section{Effect of Metasedimentary Sources on Granitic Magma and Role of Fluids}

The $\delta^{18} \mathrm{O}$ values of quartz in biotite and siliceous schists are relatively elevated compared to the values obtained from quartz in granites (Fig. 5a and Table 1). This clearly indicates their preservation in the sedimentary source. Terabayashi et al. (2010) proposed that siliceous schists were subjected to hydrothermal alteration of silicic fluids that formed these rocks however the age of silicification event in the biotite schist is unknown. It is considered that silicification was coeval to or slightly after the Ryoke metamorphism in this area and earlier than the formation of the foliation-normal quartz veins that penetrate the siliceous schists. The relatively higher $\delta^{18} \mathrm{O}$ values $(\sim+17 \%)$ in quartz veins suggest their precipitation from fluids that were possibly liberated during metamorphic dehydration from the metasedimentary precursors at a later stage ca. $<90 \mathrm{Ma}$, as indicated by their cross-cutting or foliation normal structure within the schists. It is hard to find zircons in the fine-grained and late-stage veins; hence their geochronological information is unclear. However, based on the characteristics of their structural settings, such as being foliation-normal, cutting-across the biotite and siliceous schists, and some of the early-formed (foliation-parallel) veins, these are assumed to be the youngest in the area $(<90 \mathrm{Ma})$. Metamorphic dehydration from the

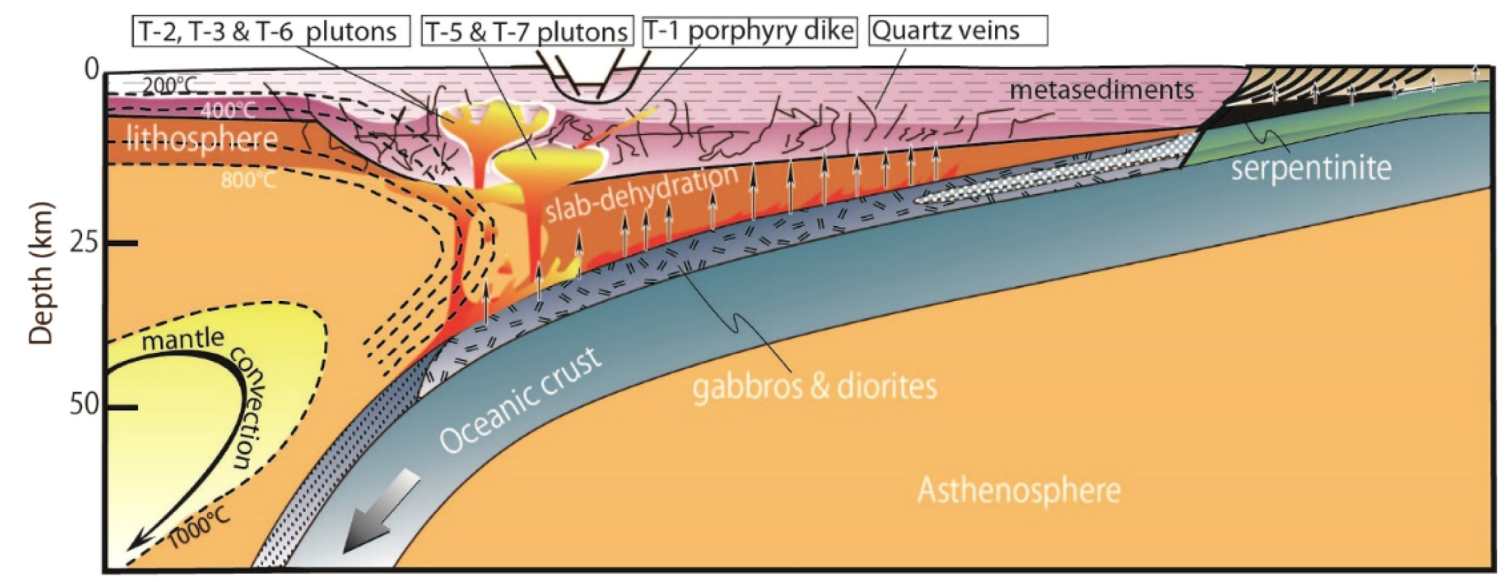

Figure 8. Schematic section showing the Paleo-Pacific subduction beneath the Japanese Islands (based on published literature on the Ryoke belt plutonism; Nakajima, 1994; Okudaira and Suda, 2001; Kawakami and Ikeda, 2003; Iida et al., 2015; Skrzypek et al., 2016, 2018; Mateen et al., 2019). Due to slab-subduction dehydration, serpentinization at mantle-wedge and felsic magma generation due to partial melting of the crustal material formed the Ryoke granitic plutons and associated high-temperature metamorphic rocks. Early-formed granites (referred to as T2, T-3, and T-6 plutons) assimilated sedimentary and older crustal material therefore acquiring relatively higher $\delta^{18} \mathrm{O}$ values. Latter plutons (referred to as T-5 and T-7 plutons) formed from the influx of new magma that was relatively uncontaminated, hence, they acquired lower $\delta^{18} O$ values. Late-stage magmatism (referred as T-1 porphyry dyke) was also formed from the less-contaminated magma and therefore had lower $\delta^{18} O$ values. Quartz veins were formed from fluids derived from metamorphic dehydration and penetrated through the metasediments that had elevated $\delta^{18} O$ values. Temperature isotherms in the crust and mantle are adopted from Stern (2002). 
accretionary complex within or above the subducting slab is a possible cause that likely produced those silica-rich fluids.

\section{Schematic Model}

Here we present a schematic model (Fig. 8) that illustrates the subduction of the Paleo-Pacific oceanic crust beneath the Japanese Islands during the Pre-Cretaceous times. This subduction is a plausible reason for the formation of well-known paired metamorphic belts in Japan. The subducting plate on the oceanside was mafic, and hence produced the HP/LT Sanbagawa metamorphic belt. The overriding plate on the continental side served as a heat source to cause partial melting of crust in order to generate the granite magma that intruded into the metasedimentary sequences at the back-arc basin, due to the slab-dehydration. The uprising magma from the continental crust with some mafic component, may have assimilated the preexisting metasedimentary precursors to form the older plutons (such as T-3 and T-6 plutons) with comparatively higher $\delta^{18} \mathrm{O}$ values (Fig. 8 ). In contrast, younger plutons (such as the T-5 pluton) were formed from a young and juvenile crust that had relatively increased maficity due to the next stage magmatic influx, possibly after the slab role-back, and had comparatively lower $\delta^{18} \mathrm{O}$ values (close to the typical I-type granites) indicting little or no effect from the metasedimentary precursors. The late-stage porphyry dike (T-1) was also likely produced from the relatively uncontaminated granitic magma, and preserved similar $\delta^{18} \mathrm{O}$ values to those found in T-5 and T-7 plutons.

Quartz veins were produced from the late-stage dehydration-related fluids that were liberated from the metasedimentary source, and therefore acquired similar $\delta^{18} \mathrm{O}$ values to the schists, and elevated $\delta^{18} \mathrm{O}$ values comparted to neighboring granites. The $\mathrm{Si}-$ and ${ }^{18} \mathrm{O}$-rich fluids penetrated through the upper crustal layers, some precipitated in concordant relations whereas the final stage veins (we don't know their age yet but due to the cross-cutting nature of the country rocks, they are considered to be the youngest) infiltrated through the biotite and siliceous schists.

\section{Conclusions}

The parental magma from which granites in the San-yo and Ryoke belts crystallized, was initially derived from partially molten crust that was chemically modified by metasedimentary precursors which elevated their $\delta^{18} \mathrm{O}$ values. Oxygen and Hf isotope data provide compelling evidence for the incorporation of crustal (sedimentary source) component that generally modified the parental magma. Close to zero or negative $\varepsilon_{\mathrm{Hf}}(\mathrm{t})$ values in some of the analyzed zircon grains from the older granitoids (ca. T-2, T-3, and T-6) attest to the incorporation of a recycled continental crustal component. In contrast, younger plutons (ca. T1 and T5), preserving relatively lower $\delta^{18} \mathrm{O}$ values indicate younger and uncontaminated crust with increased maficity. Quartz veins that penetrate the metasedimentary successions were likely generated from the silica- and ${ }^{18} \mathrm{O}$-rich fluids that were produced as a result of the late-stage slab-dehydration process and acquired elevated $\delta^{18} \mathrm{O}$ values from their metasedimentary precursors.

\section{Acknowledgement}

We thank three anonymous reviewers for their critical and constructive comments that significantly improved the presentation and interpretation section. Due thanks to Elizabeth J. Catlos, associate editor of the journal Episodes for editorial handling and useful advice. We appreciate English language proofreading by Dr. Bo Causer of Kagoshima University. This study was supported partly by the JSPS research fund (KAKENHI\#: 22540472 to HY, and \#15K05316 and \#20K004135 to HUR).

\section{References}

Akasaki, E., Kamei, A., and Owada, M., 2013, Magma process of the Kibe Granite (One of the Younger granitoids) in the Yanai area of the Ryoke Belt, southwest Japan. Japanese Magazine of Mineralogical and Petrological Sciences, v. 42, pp. 159-173. (In Japanese with English abstract).

Akasaki, E., Owada, M., and Kamei, A., 2015, Crustal differentiation due to partial melting of granitic rocks in an active continental margin, the Ryoke Belt, Southwest Japan. Lithos, v. 230, pp. 82-91.

Banno, S., and Nakajima, T., 1992. Metamorphic belts of Japanese Islands. Annual Review of Earth and Planetary Sciences, v. 20, pp. 159-179.

Bonin, B., Janoušek, V., and Moyen, J. F., 2020, Chemical variation, modal composition and classification of granitoids. Geological Society, London, Special Publication, v. 491, pp. 9-51.

Brown, M., 1998, Unpairing metamorphic belts: P-T paths and a tectonic model for the Ryoke Belt, southwest Japan. Journal of Metamorphic Geology, v. 16, pp. 3-22.

Brown, M., 2010, Paired metamorphic belts: revisited. Gondwana Research, v. 18 , pp. $46-59$.

Clayton, R.N., and Mayeda, T.K., 1963, The use of bromine pentafluoride in the extraction of oxygen from oxides and silicates for isotope analysis. Geochimica et Cosmochimica Acta, v. 27, pp. 43-52.

Clemens, J.D., Stevens, G., and Farina, F., 2010, The enigmatic sources of I-type granites: The peritectic connexion. Lithos, v. 126, pp. 174-181.

Czamanske, G., Ishihara, S., and Atkin, S.A., 1981, Chemistry of rockforming minerals of the Cretaceous-Paleocene batholith in southwestern Japan and implications for magma genesis. Journal of Geophysical Research, Solid Earth, v. 86, pp. 10431-10469.

Eiler, J.M., McInnes, B., Valley, J.W., Graham, C.M., and Stolper, E.M., 1998, Oxygen isotope evidence for slab-derived fluids in the sub-arc mantle. Nature, v. 393, pp. 777-781.

Frost, B.R., Barnes, C.G., Collins, W.J., Arculus, R.J., Ellis, D.J., and Frost, C.D., 2001, A geochemical classification for granitic rocks. Journal of Petrology, v. 42, pp. 2033-2048.

Frost, B.R., and Frost, C.D., 2008, A geochemical classification for feldspathic igneous rocks. Journal of Petrology, v. 49, pp. 1955-1969.

Harris C., Faure, K., Diamond R.E., and Scheepers R., 1997, Oxygen and hydrogen isotope geochemistry of S- and I-type granitoid: The Cape Granite suite, South Africa. Chemical Geology, v. 143, pp. 95-114.

Hayasaka, Y., Isozaki, Y., and Hara, I., 1983, Discovery of Jurassic radiolarians from the Kuga and Kanoashi Groups in the western Chugoku, southwest Japan. Journal of the Geological Society of Japan, v. 89, pp. 527-530 (in Japanese).

Herzig, C.T., Kimbrough, D.L., Tainosho, Y., Kagami, H., Iizumi, S., and Hayasaka, Y., 1998, Late Cretaceous U/Pb zircon ages and Precambrian crustal inheritance in Ryoke granitoids, Kinki and Yanai districts, Japan. Geochemical Journal, v. 32, pp. 21-31.

Higashimoto, S., Nureki, T., Hara, I., Tsukuda, E., and Nakajima, T., 1983, Geology of the Iwakuni district. Quadrangle Series, Scale 1:50,000, Geological Survey of Japan, (79 p.) (in Japanese with English abstract). 
Hoefs, J., 2009, Stable Isotope Geochemistry (6th edition). Springer-Verlag, Berlin, $285 \mathrm{p}$.

Honma, H., and Sakai, H., 1975, Oxygen isotope study of metamorphics ad granitic rocks of the Yanai districts in the Ryoke Belt, Japan. Contributions to Mineralogy and Petrology, v. 52, pp. 107-120.

Iida, K., Iwamori, H., Orihashi, Y., Park, T., Jwa, Y-J., Kwon, S-T., Danhara, T., and Iwano, H., 2015, Tectonic reconstruction of batholith formation based on the spatiotemporal distribution of Cretaceous-Paleogene granitic rocks in southwestern Japan. Island Arc, v. 24, pp. 205-220.

Ikeda, T., 1993, Compositional zoning patterns of garnet during prograde metamorphism from the Yanai district, Ryoke metamorphic belt, southwest Japan. Lithos, v. 30, pp. 109-121.

Ikeda, T., 1998, Progressive sequence of reactions of the Ryoke metamorphism in the Yanai district, southwest Japan: the formation of cordierite. Journal of Metamorphic Geology, v. 16, pp. 39-52.

Ikeda, T., 2004, Pressure-temperature conditions of the Ryoke metamorphic rocks in Yanai district, SW Japan. Contributions to Mineralogy and Petrology, v. 146, pp. 577-589.

Imai, N., Terashima, S., Itoh, S., and Ando, A., 1995, 1994 compilation values for GSJ reference samples, "Igneous rock series". Geochemical Journal, v. 29, pp. 91-95.

Ishihara, S., 1977, The magnetite-series and ilmenite-series granitic rocks. Mining Geology, v. 27, pp. 293-305.

Ishihara, S., and Matsuhisa, Y., 2002, Oxygen isotope constraints on the geneses of the Cretaceous-Paleogene granitoids in the Inner Zone of Southwest Japan. Bulletin of the Geological Survey of Japan, v. 53, pp. 421-438.

Ishihara, S., and Chappell, B.W., 2007, Chemical composition of the late Cretaceous Ryoke granitoids of the Chubu District, central Japan - Revisited. Bulletin of the Geological Survey of Japan, v. 58, pp. 323-350.

Isozaki, Y., 1996, Anatomy and genesis of a subduction-related orogen: a new view of geotectonic subdivision and evolution of the Japanese Islands. Island Arc, v. 5, pp. 289-320.

Iwao, S., 1936, On some basic inclusions in granite f Kuga district, Nagato; a study on contamination. Japanese Journal of Geology and Geography, v. 13 , pp. $155-162$.

Iwao, S., 1940, The Origin of the Basic Inclusions in the Granitic Rocks of the Yanai District, Japan, and their Petrographic Features. Japanese Journal of Geology and Geography, v. 17, pp. 45-62.

Jahn, B.M., 2010, Accretionary orogen and evolution of the Japanese Islands: Implications from a Sr-Nd isotopic study of the Phanerozoic granitoids from SW Japan. American Journal of Science, v. 310, pp. 1210-1249.

Kagami, H., Honma, H., Shirahase, T., and Nureki, T., 1988, Rb-Sr whole rock isochron ages of granites from northern Shikoku and Okayama, Southwest Japan: implications for the migration of the late Cretaceous to Paleogene igneous activity in space and time. Geochemical Journal, v. 22, pp. 69-79.

Kagami, H., Iizumi, S., Tainosho, Y., and Owada, M., 1992, Spatial variation of $\mathrm{Sr}$ and $\mathrm{Nd}$ isotope ratios of Cretaceous-Paleogene granitoid rocks, Southwest Japan Arc. Contributions to Mineralogy and Petrology, v. 111, pp. 165-177.

Kawakami, T., and Ikeda, T., 2003, Boron in metapelites controlled by the breakdown of tourmaline and retrograde formation of borosilicates in the Yanai area, Ryoke metamorphic belt, SW Japan. Contributions to Mineralogy and Petrology, v. 145, pp. 131-150.

Kawakami, T., 2004, Tourmaline and boron as indicators of the presence, segregation and extraction of melt in pelitic migmatites: examples from the Ryoke metamorphic belt, SW Japan. Earth and Environmental Science Transactions of the Royal Society of Edinburgh, v. 95, pp. 111-123.

Kawakami, T., and Kobayashi, T., 2006, Trace element composition and degree of partial melting of pelitic migmatites from the Aoyama area, Ryoke metamorphic belt, SW Japan: Implications for the source region of tourmaline leucogranites. Gondwana Research, v. 9, pp. 176-188.
Kawano, Y., and Ueda, Y., 1966, K-Ar dating on the igneous rocks in Japan (V) - granitic rocks in southwestern Japan. Journal of the Japanese Association of Mineralogists, Petrologists and Economic Geologists, v. 56, pp. 191-211. (In Japanese with English abstract).

Koide, H., 1958, Dando granodioritic intrusives and their associated metamorphic complex. Japan Society for the Promotion of Science, 311p.

Kojima, G., 1953, Contributions to the knowledge of mutual relations between three metamorphic zones of Chugoku and Shikoku, Southwestern Japan, with special reference to the metamorphic and structural features of each metamorphic zone. Journal of science of the Hiroshima University. Series C, Geology, v. 1, pp. 17-46.

Kolodny, Y., and Epstein, S., 1976, Stable Isotope geochemistry of deepsea cherts. Geochimica et Cosmochimica Acta, v. 40, pp. 1195-1209.

Kröner A., Kovach V., Belousova E., Hegner E., Armstrong R., Dolgopolova A., Seltman R., Alexeieve D.V., Hofmann J.E., Wong J., Sun M., Cai K., Wang T., Tong Y., and Wilde S.A., 2014, Reassessment of continental growth during the accretionary history of the Central Asian Orogenic Belt. Gondwana Research, v. 25, pp. 103-125.

Maruyama, S., Isozaki, Y., Kimura, G., and Terabayashi, M., 1997, Paleogeographic Maps of the Japanese Islands: plate tectonic synthesis from 750 Ma to the present. Island Arc, v. 6, pp. 121-142.

Mateen, T., Yamamoto, H., Rehman, H.U., and Terabayashi, M., 2015. Ductility contrast induced by silicification in pelitic schist of the Ryoke metamorphic belt, Japan. Journal of Structural Geology, v. 80, pp. 38-46.

Mateen, T., Okamoto, K., Chung, S-L., Wang, K-L., Lee, H-Y., Abe, S., Mita, Y., Rehman, H.U., Terabayashi, M., and Yamamoto, H., 2019, LA-ICP-MS zircon U-Pb age and Hf isotope data from the granitic rocks in the Iwakuni area, Southwest Japan: reevaluation of emplacement order and the source magma. Geosciences Journal, v. 23, pp. 917-931.

Matsuhisa, Y., Honma, H., Matsubaya, O., and Sakai, H., 1972, Oxygen isotopic study of the Cretaceous granitic rocks in Japan. Contributions to Mineralogy and Petrology, v. 37, pp. 65-74.

Miyashiro, A., 1961, Evolution of metamorphic belts. Journal of Petrology, v. 2, pp. 277-311.

Miyashiro, A., 1967, Orogeny, regional metamorphism, and magmatism in the Japanese Islands. Meddelelser Fra Dansk Geologisk Forening, v. 17, pp. 390-446.

Miyashiro, A., 1973, Metamorphism and metamorphic belts. George Allen and Unwin, London, $492 \mathrm{p}$.

Muehlenbachs, K., 1998, The oxygen isotopic composition of the oceans, sediments and the seafloor. Chemical Geology, v. 145, pp. 263-273.

Nakajima, T., Shirahase, T., and Shibata, K., 1990, Along-arc variation of $\mathrm{Rb}-\mathrm{Sr}$ ages of Cretaceous granitic rocks in Southwest Japan. Contributions to Mineralogy and Petrology, v. 104, pp. 381-389.

Nakajima, T., Williams, I.S., and Watanabe, T., 1993, SHRIMP U-Pb ages of the Ryoke and San-Yo granitoids in southwest Japan. Geological Society of Japan Annual Meeting, Abstracts No. 100, p. 584. (in Japanese).

Nakajima, T., 1994, The Ryoke plutonometamorphic belt: crustal section of the Cretaceous Eurasian continental margin. Lithos, v. 33, pp. 51-66.

Nakajima, T., 2018, Granites of Japan: A review at 2017. The Journal of Geological Society of Japan, v. 124, pp. 603-625. (in Japanese with English abstract)

Nureki, T., 1974, Contact metamorphism in the So-o district, Yamaguchi Prefecture, Japan - with special reference to the occurrence of sillimanite. Memoirs of the Geological Society of Japan, v. 11, pp. 251-281.

Okamura, Y., 1957, Structure of the Ryoke metamorphic and granodioritic rocks of the Yanai district, Yamaguchi Prefecture. Journal of the Geological Society of Japan, v. 63, pp. 684-697. (in Japanese with English abstract)

Okamura, Y., 1960, Structural and petrological study of the Ryoke gneiss and granodiorite complex of the Yanai district, SW Japan. Journal of science of the Hiroshima University. Series C, Geology, v. 3, pp. 143214. 
Okano, O., and Honma, H., 1983, Sr isotope ratio of the Ryoke and Hiroshima granitic rocks in the Yanai district. MAGMA, v. 67, pp. 123128. (in Japanese)

Okudaira, T., Hara, I., Sakurai, Y., and Hayasaka, Y., 1993, Tectono-metamorphic processes of the Ryoke belt in the Iwakuni-Yanai district, southwest Japan. Memoirs of the Geological Society of Japan, v. 42, pp. 91-120.

Okudaira, T., Hara I., and Takeshita, T., 1995, Emplacement mechanism of the Older Ryoke granites in the Yanai district, southwest Japan, with special reference to extensional deformation in the Ryoke metamorphic belt. Journal of Science of Hiroshima University, Series C, v.10, pp. 357-366.

Okudaira, T., Beppu, Y., Yano, R., Tsuyama, M., and Ishii, K., 2009, Midcrustal horizontal shear zone in the forearc region of the mid-Cretaceous SW Japan arc, inferred from strain analysis of rocks within the Ryoke metamorphic belt. Journal of Asian Earth Sciences, v. 35, pp. 34-44.

Okudaira, T., and Suda, Y., 2011, Cretaceous events at the Eastern margin of East Asia recorded in rocks of the Ryoke belt, SW Japan. Journal of Geography, v. 120, pp. 452-465 (in Japanese with English abstract).

Owada, M., Midorikawa, T., and Imaoka, T., 2014, K-Ar ages of lowgrade metapelites from the Ryoke belt, the Iwakuni district, Yamaguchi Prefecture, Japan. Journal of the Geological Society of Japan, v. 120, pp. 413-418. (in Japanese with English abstract).

Owada, M., Tanaka, S., Yuhara, M, and Kagami, H., 1995, Rb-Sr whole rock isochron age of the Habu granodiorite in the eastern Yamaguchi Prefecture. Journal of Mineralogy, Petrology and Economic Geology, v. 90, pp. 358-364.

Peccerillo, A., and Taylor, S.R., 1976. Geochemistry of Eocene calc-alkaline volcanic rocks from the Kastamonu area, Northern Turkey. Contributions to Mineralogy and Petrology, v. 58, pp. 63-81.

Rehman, H.U., Khan, T., Lee, H-Y., Chung, S-L., Jan, M. Q., Zafar, T., and Murata M. 2021, Petrogenetic source and tectonic evolution of the Neoproterozoic Nagar Parkar Igneous Complex granitoids: Evidence from zircon $\mathrm{Hf}$ isotope and trace element geochemistry. Precambrian Research, v. 354, 106047. doi:10.1016/j.precamres.2020.106047

Shand, S.J., 1943, In: Eruptive ROCKS. D. Van Nostrand Company, New York, $360 \mathrm{p}$.

Shigeno, H., and Yamaguchi, M., 1976, A Rb-Sr isotopic study of metamorphism and plutonism in the Ryoke belt, Yanai district, Japan. Journal of the Geological Society of Japan, v. 82, pp. 687-698. (in Japanese with English abstract).

Skrzypek, E., Kawakami, T., Hirajima, T., Sakata, S., Hirata, T., and Ikeda, T., 2016, Revisiting the high temperature metamorphic field gradient of the Ryoke Belt (SW Japan): New constraints from the IwakuniYanai area. Lithos, v. 260, pp. 9-27.

Skrzypek, E., Kato, T., Kawakami, T., Sakata, S., Hattori, K., Hirata, T., and Ikeda T., 2018, Monazite Behaviour and Time-scale of Metamorphic Processes along a Low-pressure/High-temperature Field Gradient (Ryoke Belt, SW Japan). Journal of Petrology, v. 59, pp. 1109-1144.

Stern, R.J., 2002, Subduction zones. Reviews of Geophysics, v. 40, 1012, doi:10.1029/2001RG000108

Suzuki, K., and Adachi, M., 1998, Denudation history of the high T/P Ryoke metamorphic belt, southwest Japan: constraints from CHIME monazite ages of gneisses and granitoids. Journal of Metamorphic Geology, v. 16, pp. 23-38.

Suzuki, K., Adachi, M., and Nureki, T., 1996, CHIME age dating of monazites from metamorphic rocks and granitic rocks of the Ryoke belt in the Iwakuni area, Southwest Japan. Island Arc, v. 5, pp. 43-55.

Terabayashi, M., Yamamoto, H., Hiwatashi, E., and Kitajima, K., 2010, Silicification of the pelitic schist in the Ryoke low-pressure/temperature metamorphic belt, Southwest Japan: Origin of competent layers in the middle crust. Island Arc, v. 19, pp. 17-29.

Valley, J.W., Lackey, J.S., Cavosie, A.J., Clechenko, C.C., Spicuzza, M.J., Basei, M.A.S., Bindeman, I.N., Ferreira, V.P., Sial, A.N., King, E.M.,
Peck, W.H., Sinha, A.K., and Wei, C.S., 2005, 4.4 billion years of crustal maturation: oxygen isotope ratios of magmatic zircon. Contributions to Mineralogy and Petrology, v. 150, pp. 561-580.

Vervoort J.D., Patchet P.J., Gehrels G.E., and Nutman A.P., 1996, Constraints on the early Earth differentiation from hafnium and neodymium isotopes. Nature, 379, pp. 624-627.

Vervoort J.D., Patchet P.J., Blichert-Toft J., and Albarède F., 1999, Relationship between $\mathrm{Lu}-\mathrm{Hf}$ and $\mathrm{Sm}-\mathrm{Nd}$ isotopic systems in the global sedimentary system. Earth and Planetary Science Letters, v. 168, pp. 79-99.

Vervoort, J.D., and Kemp, A.I.S., 2016, Clarifying the zircon Hf isotope record of crust-mantle evolution. Chemical Geology, v. 425, pp. 65-75.

Wallis S.R., Okudaira, T., 2016, Paired metamorphic belts of SW Japan: the geology of the Sanbagawa and Ryoke metamorphic belts and the Median Tectonic Line. Moreno T., Wallis, S., Kojima T., and Gibbons W. (eds) "The Geology of Japan, Geological Society, London, Geology of Series, pp. 101-124 (doi.org/10.1144/GOJ.4).

Watson E.B., and Harrison T.M., 1983, Zircon saturation revisited: temperature and composition effects in a variety of crustal magma types. Earth and Planetary Science Letters, v. 64, pp. 295-304.

Yamamoto, H., 1962, Plutonic and metamorphic rocks along the UsukiYatsushiro tectonic line in the western part of central Kyushu. Bulletin of Fukuoka Gakugei University, v. 12, pp. 93-172.

Yamamoto, H., 1994, Kinematics of mylonitic rocks along the Median Tectonic Line, Akaishi Range, central Japan. Journal of Structural Geology, v. 16, pp. 61-70.

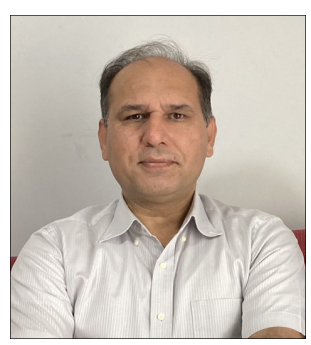

Hafiz Ur Rehman, Ph.D., Associate Professor at Kagoshima University's Graduate School of Science and Engineering, conducting teaching and research related to petrology, mineralogy, geochemistry, and tectonics, particularly metamorphic geology and Himalayan tectonics.

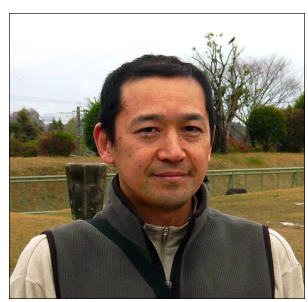

Hiroshi Yamamoto, Ph.D., Professor at Kagoshima University's Graduate School of Science and Engineering, engaged in teaching and research on structural geology, petrology, and tectonics

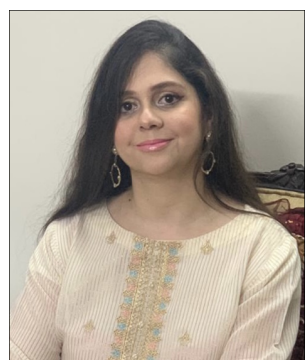

Tayyaba Mateen, Ph.D., researcher and a mother of 3 kids, have interests in structural geology, microfabric, and, tectonics. 